\title{
CEZALANDIRMANIN AMACI VE BU BAĞLAMDA ÜTOPYALAR ÜZERİNE BİR DEĞERLENDİRME*
}

DOI: https://doi.org/10.33717/deuhfd.704815

\author{
Arş. Gör. Havva Begüm TOKGÖZ $Z^{* *}$
}

\section{Öz}

Bu çalışmanın temel amacı, türlerinin başarll birer örneği olan Thomas More'un Ütopyası ile George Orwell'in 1984'ünde cezalandırmanın amacına ilişkin hangi teoriden hareket edildiğini tespit etmektir. Bu hususun önemi, suç ve ceza öngören kanunların yapılması ve uygulanması aşamalarında, esas amacın ne olduğunun unutulmaması gerektiğini ortaya koymak noktasında kendisini göstermektedir. Çalışmamız ile güttüğümüz temel amaca ulaşabilmek bakımından öncelikle cezalandırmanın amacı ile yakından ilişkisi bulunan cezanın meşruiyeti ve cezalandırma yetkisi konuları kısaca ele alınmıştır. Ardından cezalandırmanın amacına ilişkin teorilerin ve bu teoriler kapsamında öne sürülen çeşitli görüşlerin neler olduğu açıklanmıştır. Günümüze kadar ileri sürülen teoriler; mutlak teoriler, nispi teoriler ve karma teori şeklinde üç başlık altında toplanmaktadır. Bunlar içerisinde de mutlak teoriler, adalet ve kefaret teorisi şeklinde; nispi teoriler ise genel önleme ve özel önleme teorisi şeklinde iki alt başlı̆̆a ayrllmaktadır. Çalışmada, söz konusu teorik bilgilere yer verildikten sonra devlet ve ütopya kavramları da kısaca ele alınmıştır. Bu kapsamda ütopya kavramı, yalnızca olumlu anlamını değil, olumsuz anlamını (distopya) da kapsayacak şekilde kullanılmıştır. Ardından incelemek üzere seçilen iki eser, cezalandırmanın amacına ilişkin teoriler bakımından değerlendirme imkânı să̆layacak noktalardan hareket ederek değerlendirmeye tâbi tutulmuştur. Son olarak ütopyalarda cezalandırmanın amacına dair hangi teorinin esas alındığ sorusu cevaplanmiştır.

Bu çalışmanın hazırlanması aşamasında görüşleriyle katkıda bulunan saygıdeğer hocalarım Prof. Dr. Adem Sözüer, Prof. Dr. Fethi Gedikli ve Dr. Rahime Erbaş'a teşekkür ederim.

** İstanbul Üniversitesi Hukuk Fakültesi, Ceza ve Ceza Muhakemesi Hukuku Anabilim Dal1 (e-posta: btokgoz@istanbul.edu.tr) ORCID: https://orcid.org/0000-0001-6296-5068 (Makalenin Geliş Tarihi: 31.10.2019) (Makale Gönderilme Tarihi: 01.11.2019/Makale Kabul Tarihi: 23.01.2020) 


\title{
Anahtar Kelimeler
}

Ceza, cezalandırmanın amacı, suç önleme, devlet, ütopya

\section{THE PURPOSE OF PUNISHMENT AND AN ASSESSMENT ON UTOPIAS IN THIS CONTEXT}

\begin{abstract}
The main goal of this study is to explain the theories which have been put forward about the purpose of punishment and to examine the theories which are used in the Thomas More's Utopia and George Orwell's 1984, with analyzing these two books which are one of the examples of utopias. This issue is important in terms of demonstrating what is the purpose of punishment should be remembered, both during the process of law-making and the implementation of the regulations that foresee crime and punishment. In order to achieve the aim pursued with this work, first of all the legitimacy of punishment and the issue of jurisdiction were briefly discussed. Then the theories about purpose of punishment were tried to explain. After referring the concepts of state and utopia in brief, it has been tried to determine which theory can be based on the purpose of punishment in these two books. Meanwhile, it should be noted here that the concept of utopia is used as a higher concept which includes the negative design of the state, in other word dystopia, in addition to its positive meaning.
\end{abstract}

\section{Keywords}

Punishment, the purpose of punishment, crime prevention, state, utopia

\section{Extended Abstract}

In choosing the subject of this study, we have acted on the question of how can be based the aim of punishment not only in the existing states but also in the states that should have been or should not have been. The aim of this question is to show what is the purpose of this laws should be remembered in both of the phases of law-making and implementation of the laws which is foreseen crime and punishment. Both of these phases have crucial importance because of the basic principles of criminal law for determining if being a state which is desirable or undesirable.

First of all, we tried to briefly explain the legitimacy of the punishment and the issue of jurisdiction. Then we mentioned what is the theories on the purpose 
of punishment. The first one of these theories is retribution theory and according to this theory, the punishment is the only purpose of punishment in itself. In addition, this purpose is to make the offender pay the redemption or to perform the punishment in order to fulfill the justice under every kind of conditions. According to the retribution theory, society must be protected with applying punishment, not from the person who committed a crime. In order to provide the protection of society, the offender must be removed from the society. Besides, according to these theories, the rehabilitation of the offender is not one of the purposes of punishment.

After referring the retribution theory, the deterrence theories were discussed. In terms of deterrence theories, the purpose of punishment is defined as a tool divided into two different theories as general prevention and special prevention. According to the general prevention theory, the purpose of punishment is to provide deterrence by preventing other individuals from committing a crime. According to special prevention theory, the purpose of punishment is to prevent the person who committed a crime from recidivism and provide to reintegration of him/her to the society through the rehabilitation of that person.

It should be noted here that, even if in order to ensure general prevention, the applying of punishment as a means of keeping the society under control, can harm the fundamental rights and freedoms, because punishment is the most severe legal sanction. In this respect, especially in modern criminal law of nowadays, the understanding that the "punishment should provide redemption" is largely abandoned. According to the purpose of prevention, punishment should be determined in such a way that the offender can be reintegrated to the society and proportionate to him/her culpability. Because the purpose of the prevention is to ensure that the punishment which is fulfilled only in this way. Moreover, as it is understood from practice and supported by criminological researches, there is no doubt that the penalties cannot be achieved the aim by having a frightening and deterrent effect, by being heavy or violent.

Eventually, we should state that it is not possible to deny, the aspect of redemption of punishment. But especially nowadays this is not enough to justify the punishment. Moreover, we should not act with a sense of justice that will vary according to each period and every country. Because it will not be possible to present an absolute and general scale by moving from a point that differs in this way.

In the last part of this study, we tried to evaluate the following two books: George Orwell's 1984 and Thomas More's Utopia. As a result of the analysis we made by adopting comparative method on the points, we have realized that is related to the purpose of punishment in the mentioned books, the theory 
accepted in More's Utopia is the combined theory which contains both of the retribution and prevention theories. We have come to the conclusion that in Orwell's 1984, retribution theory is dominant.

Consequently, as in More's Utopia, we need to point out that in the modern criminal law understanding, the combined theory which considers retribution and prevention theories in an eclectic way is accepted. On the other hand, in Orwell's 1984, in a way incompatible with the modern criminal law, the retribution theory which acts on the view of redemption has been accepted. It has been determined that even the necessities of being human have been completely denied in this kind of system. 


\section{GİRIŞ}

$\mathrm{Bu}$ çalışmada güttüğümüz temel amaç, öncelikle cezalandırmanın amacına ilişkin öne sürülmüş olan teorileri açıklamak ve bu bağlamda birer ütopya ve distopya örneği olan iki eseri birbiriyle karşılaştırmak suretiyle inceleyerek bu eserlerde hangi teorilerin benimsendiğini ortaya koymaktır. Ancak öncelikle belirtmemiz gerekir ki çalışmamızda ütopya kavramı, aşağıda kavrama ilişkin tanımı yaparken de ifade edeceğimiz üzere, bir üst kavram olarak kullanılmıştır. Zira Türkçe'de her ikisi de ütopya olarak anılıyor olmasına rağmen, ütopya kavramı, outopia şeklinde "olmayan yer"; eutopia şeklinde ise "iyi ve güzel yer" anlamına gelmektedir. Bu bakımdan çalışmamızda ütopya kavramı, olumlu anlamdaki kullanımının yanı sıra, olumsuz anlamdaki devlet tasarımını (distopya) kapsayacak bir üst kavram olarak da kullanılmaktadır.

Söz konusu değerlendirmeyi yapacağımız eserler, benzer eserlere nazaran cezalandırmanın amacına dair verileri daha net biçimde barındırdığı gerekçesinden hareket ederek seçmiş olduğumuz, Thomas More'un Ütopya isimli eseri ile George Orwell'in 1984 isimli eseridir. Bu eserleri irdelemek suretiyle hem ideal olarak addedilen hem de olmasindan korku duyulan devlet tasarımlarında cezalandırmanın hangi amacının esas alındığını ortaya koymamız mümkün olacaktır. Kanaatimizce bu husus, suç ve ceza öngören kanunların gerek yapılması gerek uygulanması aşamasında, cezalandırmanın amacının ne olduğunun unutulmaması gerektiğini ortaya koymak bakımından önem arz etmektedir. Ayrıca hangi devlet tasarımında hangi amacin benimsendiğinden yola çıkarak kanun koyucu ile uygulamacılara, söz konusu aşamalarda, olması istenen bir devletteki gibi mi yoksa olmasından korku duyulan bir devletteki gibi mi hareket etmekte olduklarını gösterebilme imkânımız olacaktır.

Çalışmamız ile güttüğümüz amacı gerçekleştirebilmek bakımından ilk olarak cezalandırmanın amacını sorgularken akla gelen ve cezalandırmanın amacının açıklanması ile sağlam bir zemine oturtulabilen cezanın meşruiyetine ve cezalandırma ile güdülen amacı aşmayacak ölçüde tanınabilecek cezalandırma yetkisine kısaca değinilecektir. Ardından cezalandırmanın amacına ilişkin teoriler açıklanacak ve bu açıklamalardan sonra da devlet ve ütopya kavramlarının ne anlama geldiğine kısaca yer verilecektir. Son olarak yukarıda adı geçen iki eseri incelemek suretiyle çalışma kapsamında seçilen bu eserlerde benimsenen yönetim biçiminin ve buna yönelik uygulamaların, cezalandırmanın amacına ilişkin hangi teori ile temellendirilebileceği tespit edilmeye çalışılacaktır. 


\section{CEZALANDIRMA YETKİSI VE CEZANIN MEŞRUIYYTII}

Cezanın, toplumsal yaşamın ayrılmaz bir parçası olması dolayısıyla gerekliliği ve zorunluluğu hakkında ciddi tartışmalar bulunmamakla birlikte ${ }^{1}$, tanımlanması hususunda ortak bir noktaya varılamadığı görülmektedir. Söz konusu ihtilaf, cezanın zaruri unsurlarının tespit edilmesi noktasında gündeme gelmiştir².

Ceza hukuku, kişilerin haklarına ve özgürlüklerine müdahale edilmesi noktasında başvurulan son çare (ultima ratio) olma niteliğini haiz olmalıdır. Zira hak ve özgürlüklerin en fazla sınırlanabildiği alanı teşkil etmektedir. $\mathrm{Bu}$ bakımdan kişi hak ve özgürlüklerini koruma görevi olan devletin, kişilerin gerek özgürlüklerine gerek malvarlıklarına ve yaşamlarına yönelik çeşitli yaptırımlar uygulamak suretiyle müdahalede bulunmasının meşru bir zemine oturtulmas1 gerekmektedir. Ayrıca cezalandirmanın neden devlet tarafindan yapılması gerektiği de cevaplanması gereken bir soru olarak gündeme gelmektedir ${ }^{3}$.

Kişilerin her türlü hak ve özgürlüklerine yönelik gerçekleştirilecek müdahalelerin oturtulacağ mektedir. Buna göre her devletin ceza hukuku mevzuatı, belirli bir suç siyasetine dayanmalıdır. Suç işlenmesinin önlenmesini mümkün hâle getirmenin temel yolu, ceza hukuku araçlarına başvurulması olacaktır ${ }^{4}$.

$\mathrm{Bu}$ noktada günümüze gelmeden evvel cezanın meşruiyetine ilişkin birtakım argümanlar öne süren görüşleri irdelemekte fayda vardır. Örneğin $J$. $J$. Rousseau, toplumsal sözleşme kuramına göre devletin gücünün, her bireyin kendi özgürlüğünün bir parçasından vazgeçmesi ile oluştuğunu ifade etmektedir. Zira birey, topluma girmesiyle birlikte, suç işlerse cezalandırılacağını da bu yetkinin topluma, bir diğer deyişle devlete devredildiğini

1 Erem, Faruk: Ümanist Doktrin Açısından Türk Ceza Hukuku, Cilt: II, 12. Baskı, Seçkin Kitabevi, 1985, s. 150; Önder, Ayhan: Ceza Hukuku Genel Hükümler, Cilt: III, İstanbul, Beta, Eylül 1989, s. 7-8.

2 Fakat cezanın sahip olması gerektiği ifade edilen hususlar şu şekilde belirtilmiştir: ahlâkî ve insan onuruyla bağdaşır olma, suçlu yönünden etkili olma ve zorunlu hâller dışında suç işlemeyenler üzerinde etki göstermeme, bölünebilir olma, sonuçları bakımından tamir edilebilir olma ve devlete en az yükü getirme. Bkz. Demirbaş, Timur: İnfaz Hukuku, 6. Baskı, Ankara, Seçkin Yayıncılık, 2019, s. 74-75.

3 Canton, Rob: Why Punish? An Introduction to the Philosophy of Punishment, Palgrave, 2017, s. 60 .

4 Dönmezer, Sulhi: "Suç Siyaseti”, İstanbul Üniversitesi Hukuk Fakültesi Mecmuası, Cilt: 52, Say1: 1-4, 1987, 1-33, s. 7. 
baştan kabul etmiş olmaktadır ${ }^{5}$. Benzer şekilde Beccaria da devletin cezalandırma yetkisinin kaynağını toplumsal sözleşmede aramaktadır ${ }^{6}$. Bu bakımdan Beccaria'nın şu cümlesi büyük bir önem arz etmektedir: "Her insan, kamusal/ortak emanete, özgürlüğün sadece olabildiğince küçük bir parçasını vermek istemiştir. Onu başkalarına karşı savunmaya zorlayan yalnızca bu parçadır. İște bireylerin topluluk yararına vazgeçtikleri bu küçük parçaların toplamı, ceza verme hakkının temelini oluşturmaktadır", ${ }^{\text {.7 Benzer }}$ şekilde Montesquieu da cezaların acımasızca olmasını eleştirmekte ve cezaların şiddetli olmasını adaletin ve toplumsal sözleşmenin ruhuna aykırı bulmaktadır $^{8}$. Kaldı ki cezaların ağır ve şiddetli olmasının, sanılanın aksine ${ }^{9}$, caydırıcı olmakla herhangi bir ilgisi de bulunmamaktadır ${ }^{10}$.

Belirtilen görüşün aksi yönde ise Foucault, toplumsal sözleşmeyi bozan kişinin artık toplumun düşmanı hâline geleceğini ve basit bir suçun dahi tüm topluma saldırı sayılacağını belirtmiştir. Bu şekilde, cezalandırma yetkisini, "hükümdarın intikamının alınması" anlayışından, toplumun savunulması yönüne doğru çevirmiş ve bu yetkiye daha güçlü özellikler atfederek onun daha da korkutucu bir mahiyete bürünmesini sağlamıştır ${ }^{11}$. Zira ona göre iktidar, yalnızca devlet ile ilgili olmayıp toplumdaki her kesimin bünyesinde taşıyarak hayat verdiği zihinsel bir olgudur ${ }^{12}$. Kaldı ki sıradan insanların dahi

5 Taner, Tahir: Ceza Hukuku Umumî Kısım, Üçüncü Basım, İstanbul, İsmail Akgün Matbaas1, 1953, s. 24-25; Demirbaş, Timur: Ceza Hukuku Genel Hükümler, Güncellenmiş 14. Baskı, Ankara, Seçkin Yayıncılık, 2019, s. 74.

6 Aktaş, Sururi: "Cezalandırmanın Amacı Üzerine”, Erzincan Üniversitesi Hukuk Fakültesi Dergisi, Cilt: XIII, Say1: 1-2, 2009, 1-25, s. 5. Fakat belirtmek gerekir ki Beccaria, toplumsal sözleşmeyi savunduğu kadar toplumsal faydayı da savunmakta ve bu iki görüşü bir nevi birbiriyle bağdaştırmaktadır. Bkz. Taner, s. 27; Yarsuvat, Duygun: "Ceza ve Yeni İçtimai Müdafaa Doktrini”, İstanbul Üniversitesi Hukuk Fakültesi Mecmuas1, Cilt: 32, Say1: 1, 1966, 79-100, s. 83-84.

7 Beccaria, Cesare: Suçlar ve Cezalar Hakkında (Çev.: Sami Selçuk), İmge Kitabevi, 2013, s. 29.

8 Karakaş Doğan, Fatma: Cezanın Amacı ve Hapis Cezası, İstanbul, Legal Yayıncılık, 2010, s. 38.

9 Hudson, Barbara A.: Understanding Justice, 2. Bask1, Open University Press, 2003, s. 23-24.

10 Erem, s. 161; Canton, s. 88; Taner, s. 28; Hudson, s. 24.

11 Foucault, Michel: Hapishanenin Doğuşu, (Çev.: Mehmet Ali Kılıçbay), İmge Kitabevi, 2006, s. 147-148.

12 Işıktaç, Yasemin: "Ceza Adaleti Açısından Hapis Cezası ve Rehabilitasyon İlişkisi”, İstanbul Üniversitesi Hukuk Fakültesi Mecmuas1, Cilt: 71, Sayı: 1, 2013, 625-638, s. 628. 
bazı şartlar altında acımasız birer gardiyana dönüşmesi de bu hususu ortaya koymaktadir ${ }^{13}$.

Jeremy Bentham ise cezanın barındırdığı kötülüğe rağmen toplumun mutluluğunu azaltacak daha büyük kötülükleri önlemek amacıyla uygulanmasından hareket etmiş ve bu nedenle haklı ve meşru olduğunu ifade etmiş$\operatorname{tir}^{14}$. Bentham ayrıca cezanın faydasının, suçun meydana getirdiği zarardan daha yüksek olması gerektiğinden ${ }^{15}$ yola çıkmak suretiyle cezanın genel önleme amacı üzerinde durmuş ve bu şekilde sağlanacak caydırmanın, cezalandırmayı haklı kıldığını belirtmiştir ${ }^{16}$. Zira mevzu bahis faydanın, toplumun tamamının mutluluğunu kapsaması gerektiğinden her bir birey bak1mından ayrı ayrı değil, toplumun bütünü için mevcut olması gerekmektedir ${ }^{17}$. Benzer şekilde, toplumsal fayda görüşünü benimseyen Feuerbach da genel önlemeyi sağlayacak cezanın, bireylere psikolojik cebir uygulamak suretiyle yararlı olduğunu ve devletin hedeflediği toplum hayatını hukuk kurallarına göre kurmak ve korumak amacına hizmet edeceğini ileri sürmüştür ${ }^{18}$. Franz von Liszt ise cezanın, amaca uygun ve gerekli olduğu ölçüde haklı ve meşru olacağını ifade etmiştir ${ }^{19}$. Ayrıca toplumsal kontrolün sağlanabilmesi için cezanın kullanılmasında dikkatli olunması gerektiğini de

13 Bu hususu somut olarak ortaya koyan ve "Stanford Hapishane Deneyi" olarak adı geçen deney, 1971 y1lında Stanford Üniversitesi Psikoloji Bölümü Profesörü Philip Zimbardo tarafından yapılmıştır. Yirmi dört erkek üniversite öğrencisi ile yapılan ve iki hafta sürmesi planlanan bu deney, durumun kontrolden çıkması dolayısıyla altıncı gününde sonlandırılmıştır. Zira mahkûm rolünde olan gruptaki öğrenciler gerçek bir mahkûm psikolojisine bürünüp isyan çıkarmaya, gardiyan rolündeki öğrenciler de şiddete başvurup sadist eğilimler göstermeye başlamıştır. Deneye ilişkin ayrıntılı bilgi için bkz. https://www.prisonexp.org/, (Erişim tarihi: 08.10.2019).

14 Bentham, Jeremy: Ahlak ve Yasama İlkeleri, (Çev.: Ömer Saruhanlığlu- Uğur Kâşif Boyacı), İstanbul, Litera Yayıncılık, 2017, s. 159; Aktaş, s. 9; Altınok Villemin, Derya: “Ceza Kavramı, Nitelikleri, Amacı ve Sınıflandırılması", İstanbul Kültür Üniversitesi Hukuk Fakültesi Dergisi, Cilt: 16, Say1: 2, 2017, 149-162, s. 156.

15 Fletcher, George P.: "Basic Concepts of Criminal Law", New York, Oxford University Press, 1998, s. 30; Taner, s. 29. Rawls ise adaletin sağlanması için suç işlenmesi sonucunda meydana gelen zarar ile cezalandirma sonucunda meydana gelen zarar arasında bir denge kurulması gerektiğini ifade etmektedir. Bkz. Hudson, s. 48.

16 Bentham, Jeremy: Punishment and Deterrence, Oxford, 1998, s. 56.

17 Bentham, Ahlak ve Yasama İlkeleri, s. 18.

18 Demirbaş, Ceza Hukuku, s. 75.

19 Honig, Richard: "Ceza Gayeleri Nazariyesinin Tarihine Dair", (Çev.: M. Yavuz Abadan), İstanbul Üniversitesi Hukuk Fakültesi Mecmuası, Cilt: 2, Say1: 0, 1936, 413 426, s. 414. 
vurgulamıştır $^{20}$. Bu da suç işleyen kişiyi 1slah edip suç işlemeye meyilli olanları korkutmak ve 1slah edilemeyeceği anlaşılan suçluları da zararsız hâle getirmek suretiyle sağlanabilecektir ${ }^{21}$.

Tüm bu görüşler değerlendirildiğinde, elbette cezanın kendisinin de zarara neden olduğunu ve bünyesinde doğal olarak kötülük barındırdığını belirtmemiz mümkündür. Ancak daha büyük kötülüklerin önüne geçilebilmesini sağladığı müddetçe ceza, meşru ve gerekli olacaktır ${ }^{22}$. Ayrıca cezalandırma yetkisinin niçin devlete ait olduğu sorusunu da "anti sosyal bir fiile sosyal bir tepki” olarak nitelendirilen cezanın, devlet tarafindan düzenlenmesi vasıtasıyla ceza hukukuna yön kazandırılmış olacağı şeklinde cevaplamak mümkündür ${ }^{23}$. Tarihsel gelişimi içerisinde bunu sağlayan husus da merkezî iktidarın güçlenmesi olmuştur ${ }^{24}$. Belirtmek gerekir ki tüm bunlara rağmen devletin cezalandırma yetkisinin değil, yalnızca islah etme yetkisinin bulunduğu da ifade edilmektedir ${ }^{25}$.

Bazı yazarlar tarafından cezanın acı ve 1zdırap verici olması gerektiği ifade edilirken bazıları da suçlunun sslah edilmesi ve topluma yeniden kazandırılması ile suç işlemeyi önleyici bir işleve sahip olması gerektiğini haklı olarak belirtmektedir ${ }^{26}$. Ancak 1slahın, bireye zulmedilmesi ya da ac1 çektirilmesi ile ondan intikam alınması anlamına gelmediğini, aksine onu uslandırmak suretiyle bir daha suç işlememesini temin etmek şeklinde anlaşılması gerektiğini belirtmek gerekir ${ }^{27}$. Benzer şekilde, Erem tarafindan "suç işleyen kişinin ıslahını sağlamak için devletin kanunla belirleyip hükümle uyguladığı tedbir" olarak tanımlanan cezanın, acı verici olması gerektiğine dair bir ifade yer almamaktadır. Zira yazara göre acı, cezanın zaruri unsurlarından biri olmayıp asgarî düzeye indirilmelidir ${ }^{28}$. Ancak elbette cezanın,

20 Ünver, Yener: Ceza Hukukuyla Korunması Amaçlanan Hukuksal Değer, İstanbul, Seçkin Yayıncılık, 2003, s. 745.

21 Yüce, Turhan Tûfan: Ceza Hukuku Dersleri, Cilt: I, Manisa, Şafak Basım ve Yayınevi, 1982, s. 9.

22 Bentham, Punishment and Deterrence, s. 54-55; Yüce, s. 13-14.

23 Erem, s. 151.

24 Işııtaç, s. 625.

25 Yarsuvat, s. 98.

26 İçel, Kayıhan/Sokullu, Füsun/Özgenç, İzzet/Sözüer, Adem/Mahmutoğlu, Fatih Selami/Ünver, Yener: Yaptırım Teorisi, İstanbul, 2000, s. 4.

27 Üzülmez, İlhan: "Ceza Sorumluluğunun Esası ve Cezalandırmanın Amacına Dair Düşünce Hareketleri”, Atatürk Üniversitesi Erzincan Hukuk Fakültesi Dergisi, Cilt: V, Say1: 1-4, 2001, 259-294, s. 263.

Erem, s. 153. 
doğası gereği bünyesinde acı ve zarar verici olma özelliklerini de çoğu zaman taşıdığ

Tarihi seyrine bakıldığında ise cezalar, irade serbestisini esas alan ${ }^{30}$ Klasik Okul görüşünün benimsediği ödetme ve kefaret anlayışı dolayısıyla başlangıçta ölçüsüz olup daha sonra da gittikçe daha şiddetli bir hâl almıştır. Buna karşılık, cezayı toplumun korunması bakımından bir araç olarak gören Italyan Pozitivist Okulu ${ }^{31}$ tarafından savunulan ve ardından Toplumsal Savunma Akımı tarafından geliştirilerek toplumun korunmasından öte, kendine has bir dinamizmi olduğu belirtilen görüşlerin etkisi ile yumuşatılmaya başlamışıır ${ }^{32}$. Zira bu akım, cezanın kefaret teşkil etmesi anlayışına karşı çıkmaktadır ${ }^{33}$. Cezaların şiddeti bu şekilde gittikçe yumuşayarak nihayetinde günümüzdeki anlayışa ulaşılmıştır ${ }^{34}$.

Burada bahsi geçen hususlardan hareketle ceza hukukunun meşru görevinin, yalnızca hukuksal değerlerin korunmasını sağlamak olduğunu, devletlerin cezalandırma yetkisinin ise mutlak olmayıp haklı bir ölçü ile ve makul biçimde sınırlandırılması gerektiğini ifade etmemiz mümkündür. Zira cezalandırma yetkisi devletlere, kötülüğe meyilli olan kişilere acı verme ile bu kişileri küçük düşürme şeklindeki bir yetkiyi elbette ki tanımamaktadır ${ }^{35}$.

Cezalandırma yetkisini meşru kılan en önemli ölçütlerden biri, cezalandırmanın amacı olarak kendini göstermektedir. Zira devletin cezalandırma yetkisi, suç işlenmesini azaltmak ile ceza kanunlarına uygun davranılmasını ve insanların daha demokratik bir toplumda yaşamasını sağlamak amacına yöneliktir ${ }^{36}$. Demokratik bir toplumdan söz edilebilmesi için de

29 Cavadino, Michael/Dignan, James: The Penal System, 4. Bask1, Sage Publications, 2007, s. 36.

30 Tümerkan, Somay: "Klasik, Pozitivist Okullarda ve Toplumsal Savunma Hareketinde Ceza Sorumluluğunun Esası”, İstanbul Üniversitesi Hukuk Fakültesi Mecmuas1, Cilt 48, Say1: 1-4, 1983, 51-71, s. 52.

31 Pozitivist Okul taraftarları; Klasik Okulu, irade serbestisinin soyut bir kavram olması ve dolayısıyla da ahlâk ile ceza hukukunun birbirine karıştırdığı ile cezanın bir kefaret niteliğinde değil, toplumun korunması amacını taşıyan nitelikte olduğunu belirterek eleştirmiştir. Ayrıca buna göre Klasik Okul, mükerrir suçlulara verilecek cezanın ağırlaştırılması gerektiğini ifade etmesi ile kendisiyle çelişkiye düşmektedir. Zira mükerrir suçlular, suç işleme direnci azalmış kişiler olarak görülmektedir. Bkz. Tümerkan, s. 55.

32 Yarsuvat, s. 84-88.

33 Tümerkan, s. 60.

34 Karakaş Doğan, s. 35-36.

35 Ünver, s. 445-449.

36 Yüce, s. 3-4. 
devletin cezalandırma yetkisini kullanan kanun koyucunun yetkilerinin sınırsız olmaması gerektiği aşikârdır ${ }^{37}$.

Burada son olarak belirtmemiz gerekir ki Beccaria, "yeryüzünde hiçbir insanın sırf diğerlerinin iyiliği uğruna kendi özgürlüğ̈̈nün bir kismindan dahi olsa karşılıksız bir biçimde vazgeçmeyeceğini; bunun yalnızca romanlarda yer alabilecek bir düşs" olduğunu ifade etmektedir ${ }^{38}$. Çalışmamızda birer ütopya ve distopya olma niteliğini haiz kitapları cezalandırmanın amacı bağlamında inceleme fikri de buradan yola çıkarak gündeme gelmiştir. Ancak bu incelemeye geçmeden evvel, cezalandırmanın amacına ilişkin teorilere değinmemiz gerekmektedir. Zira bu sayede, cezalandırma yetkisine yönelik yapılmış olan değerlendirmelerin yanı sıra, aşağıda birer örneğinin inceleneceği ütopyalarda ve distopyalarda cezalandırmanın amacının, bu husustaki teorilerden hangisi ile temellendirilebileceğini ortaya koymamız mümkün olacaktır.

\section{CEZALANDIRMANIN AMACINA İLISSKINN TEORILER}

\section{A. Genel Olarak}

Cezalandırmanın amacı, gerek cezanın ne olduğunun tanımlanması noktasında asli önemi haiz olmas ${ }^{39}$ gerekse de devletlerin yönetim şekliyle sıkı bir ilişki içerisinde bulunması suretiyle geçmişten günümüze kadar tartışılan bir husus olup ${ }^{40}$ bu amacın ne olduğunun, tarihsel gelişimi içerisinde öncelikle iki başlık altında toplanması mümkündür ${ }^{41}$. İlk olarak cezanın, "ödetme" amacı taşıdığı ileri sürülmüştür. Mutlak teoriler adı altında toplanan bu görüşe göre her birey, işlemiş olduğu fiilin sonuçlarına katlanmak zorundadır. $\mathrm{Bu}$ sayede fail, kendi kendisiyle çatışacak ve maruz kaldığı yaptırımdan dolayı acı çekecektir. Bu şekilde adaletin tecelli etmesi sağlanacaktır ${ }^{42}$. İkinci olarak ise cezanın; toplum temelinde, bir diğer deyişle

\footnotetext{
37 Karakaş Doğan, s. 41.

38 Beccaria, s. 28.

39 Bilgiç, Şükrü: Hapsedilme, İyileştirme ve Yeniden Suç İşleme, Vadi Yayınları, Ekim 2012, s. 28.

40 Özbek, Veli Özer/Doğan, Koray/Bacaksız, Pınar/Tepe, İlker: Türk Ceza Hukuku Genel Hükümler, 9. Baskı, Ankara, Seçkin Yayıncılık, 2018, s. 45.

41 Dönmezer, Sulhi/Erman, Sahir: Nazari ve Tatbiki Ceza Hukuku, Genel Kısım, Cilt: II, Sekizinci Bası, İstanbul, Filiz Kitabevi, 1983, s. 593. Bazı yazarlar ise cezalandırmanın amacına ilişkin teorileri, yine iki başlık altında ve fakat neticeci teoriler ve neticeci olmayan teoriler şeklinde sınıflandırmaktadır. Ayrıntılı bilgi için bkz. Maden, Mehmet: Hapis Cezasına Seçenek Yaptırımlar, Ankara, Adalet Yayınevi, 2012, s. 5-72. 
genel ve bireysel temelde, bir başka deyişle özel olmak üzere "önleme" amacı taşıdı $\breve{g}$ belirtilmiştir ${ }^{43}$.

Mutlak teoriler bakımından ceza geçmişe yönelik bir etki gösterirken önleyici teoriler bakımından geleceğe yönelik bir etki göstermektedir ${ }^{44}$. Önleyici teorilere göre, suçun işlenmesinden sonra yapılması gereken iki şey vardır. Birincisi, faili topluma yeniden kazandırarak veya korkutarak ya da toplum dışına iterek yeniden suç işlemekten alıkoymaktır. İkincisi ise faili suç işlemekten alıkoymaktan öteye geçerek o failin işlediği fiilden dolayı cezalandırılması üzerinden toplumdaki diğer bireylerin suç işlemesinin önüne geçmektir. Günümüzde genel olarak kabul gören görüş ise bu iki amacı bir araya getiren karma görüştür ${ }^{45}$. Bu teori uyarınca söz konusu amaçların yalnızca biri değil, hepsi bir arada cezalandırmanın amaçları arasinda yer almaktadir ${ }^{46}$.

\section{B. Mutlak Teoriler}

Mutlak teorilere göre cezanın uygulanması, yukarıda da ifade edildiği üzere, bir araç değil, amaç olma niteliğini haizdir. Ayrıca ceza, suçun işlenmesinden sonra ve suçun işlenmesi dolayısıyla gündeme gelmesi bakımından geçmişe yönelik olacaktır ${ }^{47}$. Öyleyse cezadan herhangi bir fayda ya da netice beklenmemelidir ${ }^{48}$. Zira bu teoriye göre cezalandırmanın amacı, suçlunun topluma karşı gerçekleştirdiği eylemi nedeniyle acı ve ızdırap duyması ve işlemiş olduğu kusurlu davranışın bedelini, bir diğer deyişle kefaretini ödemesidir $^{49}$. Bu bakımdan cezanın verilmesiyle amaç da gerçekleşmiş

43 Özbek, Veli Özer: İnfaz Hukuku, 11. Baskı, Ankara, Seçkin Yayıncılık, 2019, s. 89.

44 Dönmezer/Erman, s. 593-594; Fletcher, s. 33; Öztürk, Bahri/Erdem, Mustafa Ruhan: Uygulamalı Ceza Hukuku ve Güvenlik Tedbirleri Hukuku, 18. Baskı, Ankara, Seçkin Yayıncılık, Eylül 2018, s. 453.

45 Dönmezer/Erman, s. 595; Özbek, s. 92; Yüce, s. 12. Karma teori, bir diğer deyişle uzlaştırıcı teori, başka bir sınıflandırma uyarınca eklektik teori olarak da adlandırılmakta ve Yeni Klasik Okul kapsamında değerlendirilmektedir. Bu sınıflandırma esas alındığında, Klasik Okul ile kastedilen ise mutlak teoriler ile nispi teorileri savunan görüşleri kapsamına alan okuldur. Ayrıntılı bilgi için bkz. Artuk, M. Emin/Gökcen, Ahmet: Ceza Hukuku Genel Hükümler, 12. Bask1, Ankara, Adalet Yayınevi, 2018, s. 29.

46 Özbek, s. 93.

47 Byrd, B. Sharon: "Kant's Theory of Punishment: Deterrence and its Threat, Retribution in its Execution", Law and Philosophy, Netherlands, Kluwer Academic Publishers, 1989, 151-200, s. 183; Önder, s. 8.

48 Erem, s. 156; Demirbaş, Ceza Hukuku, s. 574; Üzülmez, s. 266; Koca, Mahmut/ Üzülmez, İlhan: Türk Ceza Hukuku Genel Hükümler, Gözden Geçirilmiş ve Güncellenmiş 12. Bas1, Ankara, Seçkin Yayıncılık, 2019, s. 561.

Taner, s. 30. 
olacaktır $^{50}$. Cezanın bizatihi amaç olarak görülmesi dolayısıyla da suç ve ceza arasında, failin çekmesi gereken acının ne olduğu ve bu acının nasıl çektirileceğinin belirlenmesi gerekliliği üzerinden bir bağ kurulduğu görülmektedir ${ }^{51}$.

Mutlak teoriler kapsaminda yer alan Adalet Teorisi savunucusu olan Kant' $a$ göre, suç işleyen kişiye ceza verilmesi, ahlâkın ve kanunun mutlak emri olup adaletin bir gereği olarak ortaya çıkmaktadır ${ }^{52}$. Aksi takdirde toplumdaki her birey, işlenen suçun ortağı olacaktır ${ }^{53}$. Bununla birlikte cezaya; herhangi bir hukuki değeri, kişiyi veya toplumu korumak için değil, fail bir suç işlediği için hükmedilmesi gerektiğini ifade etmektedir ${ }^{54}$. Ayrıca Kant, hiçbir faydası olmayacak olsa bile, adaletin gereği olarak devletin suçluyu cezalandırması gerektiğini ifade etmektedir. Bunu daha somut bir şekilde ortaya koymak adına da bir örnek verir. Bu örneğe göre, bir adada yaşayan halk, adayı tamamen terk edecek olsa dahi hapishanede kalan son mahkûmun cezası da infaz edilmeli, ada bunun ardından terk edilmelidir ${ }^{55}$.

Mutlak teorilerden bir diğeri ${ }^{56}$ olarak da ifade edilen Kefaret Teorisi uyarınca ise cezanın esasını kefaret oluşturmaktadır. Bu bakımdan cezalar, geçmişe yönelik olmalı ve kötülük yapana bu kötülüğünün karşılığı, ceza ile ödetilmelidir ${ }^{57}$. Ayrıca kanunu ihlal eden kişiler cezalandırılmadığı takdirde, devletin kanun koymasına gerek kalmayacak ve aynı zamanda kişiler kanuna uygun da davranmayacaktır ${ }^{58}$. Bununla birlikte kefaret, yalnızca cezalan-

50 Centel, Nur: “Cezanın Amacı ve Belirlenmesi”, Turhan Tufan Yüce’ye Armağan, İzmir, Dokuz Eylül Üniversitesi Yayınları, 2001, 337-372 s. 337-338; Altınok Villemin, s. 154; Karakaş Doğan, s. 41-42.

51 Canton, s. 60.

52 Fletcher, s. 32; Üzülmez, s. 265.

53 Erem, s. 156.

54 Öztürk/Erdem, s. 453-454; Yüce, s. 5.

55 Hudson, s. 53; Özbek, s. 90; Demirbaş, Ceza Genel, s. 575.

56 Mutlak teoriler, burada benimsediğimiz sınıflandırma yerine, ahlâkî kefaret ve hukukî kefaret şeklinde de ikiye ayrılmaktadır. Bu tasnifte adalet teorisi, ahlâkî kefaret; kefaret teorisi olarak adlandırdığımız ve esasen Hegel tarafindan savunulan teori ise hukukî kefaret olarak adlandırılmaktadır. Bkz. Erem, s. 157. Bir diğer ayrıma göre de kefaret başta dinî anlama gelmekte iken Kant ile birlikte ahlâkî kefaret olarak kendini göstermiş; Hegel ile birlikte ise hukukî kefaret formuna bürünmüştür. Bkz. Yarsuvat, s. 82. Bunun yanı sıra kefareti dini, ahlâkî ve felsefi bir temele dayandıran görüş de mevcuttur. Bkz. Taner, s. 21. Bir diğer görüş ise kefareti, din ya da ahlâk kurallarının ihlali ile mantıki diyalektik ve estetik zaruret olmak üzere dörde ayırmaktadır. Bkz. Önder, s. 910.

57 Karakaş Doğan, s. 42.

58 Erem, s. 158. 
dırma tehdidinde bulunulmasının etkili olması dolayısıyla kontrol sağlamanın bir aracı addedilmemektedir. Kefaret aynı zamanda kişilerin, cezanın infazı ile elde edilen caydırıcılığın toplum üzerindeki yansımasını sağlayacak bir araç olarak değerlendirilmesi dolayısıyla da kontrol sağlamanın bir aracı olarak görülmektedir ${ }^{59}$.

Ancak bu teoriler, benimsenmeleri durumunda tehlikeli sonuçlar doğurabilecek olmaları dolayısıyla haklı olarak eleştirilmiştir ${ }^{60}$. Zira her kusurlu davranışın mutlak surette cezalandırılması gerektiği kabul edildiği takdirde, çeşitli ahlâk kurallarına aykırılıkların da cezalandırılması gerektiği gibi bir sonuca varılacaktır. Bu da kişi özgürlüğünü gereksiz yere sınırlayacak olması bir yana, devletin görevi olmayan bir şeyi görev edinmesi anlamına da gelecektir ${ }^{61}$. Kaldı ki ahlâk anlayışı, toplumdan topluma değiştiği gibi zaman içerisinde de farklı şekilde anlamlandırılabilmekte olup mutlak teoriler, günümüzdeki ahlâk anlayışı ile de örtüşmemektedir ${ }^{62}$. Bunun yanı sıra toplumun korunmasını ve failin yeniden topluma kazandırılmasını sağlayamaması dolayısıyla da mutlak teoriler eleştirilmiştir. Zira sırf adalet düşüncesi ile cezaya başvurulması, meşru bir amaç olarak kabul edilemeyecek ve bu bakımdan da ceza, meşruiyetini kaybedecektir ${ }^{63}$.

\section{Nispi Teoriler}

Protagoras'tan bu yana savunulan bu teoriler, Grotius, Montesquieu, Beccaria ve Feuerbach tarafından geliştirilmiştir ${ }^{64}$. Esasen mutlak teorilerin zıddı olarak ortaya atılan ve genel itibariyle genel ve özel önleme şeklinde bir ayrıma tâbi tutulan ${ }^{65}$ nispi teorilere göre ceza, başka amaçlara ulaşmayı sağlayan bir araç niteliğini taşımakta olup faydalı olduğu takdirde başvuru-

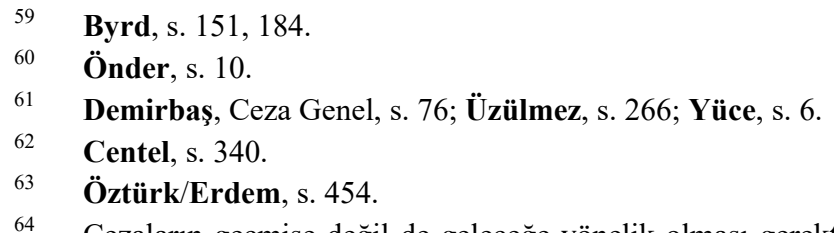

64 Cezaların geçmişe değil de geleceğe yönelik olması gerektiği hususunda öncülük eden kişi olarak bazı kaynaklarda Grotius gösterilse de esasında, ıslaha ilişkin fikirleri ve yapmış olduğu çeşitli benzetmeler dolayısıyla bu fikrin öncüsünün Protagoras olduğu belirtilmektedir. Honig, s. 418-419.

Bununla birlikte, nispi teorilerin öncelikle genel ve özel önleme şeklinde ikiye ayrılıp ardından genel önlemenin pozitif ve negatif genel önleme şeklinde ikiye ayrılmakta olduğu da görülmektedir. Bir diğer tasnife göre ise caydırma üst başlık olarak ele alınmakta ve bu da ferdî caydırma, umumî caydırma, göreli caydırma ve kısmî caydırma şeklinde dörde ayrılmaktadır. Bkz. Maden, s. 10. 
lacak bir yaptırım olarak tezahür etmektedir" ${ }^{66}$. Bu hususu Grotius, "geçmiş bir vaziyetin tekrar iadesine imkân yoktur, belki ancak gelecektekinin önüne geçilebilir" demek suretiyle açıkça ortaya koymuştur ${ }^{67}$. Bu bakımdan ceza, gelecek için verilmekte ve cezalandırma vasıtasıyla ileride işlenecek olan suçlarla da mücadele edilmektedir. Ayrıca bu sayede, toplumun yanı sıra suçlunun kendisi de suçtan korunmaktadır ${ }^{68}$.

$\mathrm{Bu}$ noktada ayrıca belirtmek gerekir ki bir zararın karşılığını zararla ödetmek şeklindeki anlayış, Kant'in savunduğu görüşü eleştiren ve nispi teorileri benimseyen birtakım yazarlar tarafından, ikna edici olamamasından da öte, ilginç olarak nitelendirilmektedir. Zira bu şekildeki bir yaklaşım, insanlara zarar vermenin yanlış olduğunu, insanlara zarar vermiş kişilere zarar vermek suretiyle ögretmek anlamına gelmektedir ${ }^{69}$.

Önleme ya da caydırıcılık teorileri olarak da adlandırılan nispi teorilerin mutlak teorilere yönelttiği ve yukarıda ifade edilen eleştiriler bir kenara, nispi teoriler de birtakım eleştirilere maruz kalmaktadır. İlk olarak nispi teorilerin etkilerinin sınırlı olduğu ve abartılmasının oldukça kolay olduğu ifade edilmektedir ${ }^{70}$. Bunun yanı sıra, önleme yaklaşımının cezayı diğer yaptırımlardan ayırt edecek bir nitelik taşımadığı, zira diğer hukukî yaptırımlarda da önleme amacının mevcut olduğu ifade edilmektedir. Ayrıca nispi teorilere; cezalandırmaya ilişkin tehdidin, suç işlemeye yönelmek konusunda kararlı olmayan kişiler bakımından etkisi olsa da suç işlemeye kesin karar vermiş ve suça büyük bir eğilimi bulunan kişileri suç işlemekten alıkoymayacağı şeklinde bir eleştiri de yöneltilmektedir ${ }^{71}$. Son olarak bu teorilere yöneltilen eleştiriler, devletin ceza verme gücünün sınırının belirlenmesinde yetersiz olduğu ve cezanın haklılık ve gereklilik nedenlerini açıklayamadığ noktalarında toplanmaktadır ${ }^{72}$.

\section{Genel Önleme Teorisi}

Genel önleme teorisi, kaynağı Aristoteles ve Hobbes'a kadar uzanan ve fakat bilimsel olarak "psikolojik zorlama" yahut "manevi cebir" şeklinde isimlendiren ve Feuerbach tarafindan savunulan bir teori olarak kendisini

66 Demirbaş, Ceza Genel, s. 576. Bu bakımdan nispi teoriler faydacı teoriler olarak da anılmış olup bir diğer adlandırma da bağlantı teorileri şeklindedir. Bkz. Önder, s. 11.

67 Honig, s. 419.

68 Karakaş Doğan, s. 44.

69 Canton, s. 63.

70 Cavadino/Dignan, s. 38.

71 Erem, s. 161.

72 Demirbaş, Ceza Genel, s. 577. 
göstermektedir $^{73}$. Genel önleme teorisi, hem hukuk bilinci oluşturarak hukuki güveni güçlendirmekte hem de bireyleri korkutmak suretiyle hukuka uygun davranışta bulunmaya yönlendirmektedir. Buradan hareketle genel önleme teorisinin, pozitif ve negatif olmak üzere ikiye ayrıldığı ileri sürülmüştür ${ }^{74}$.

$\mathrm{Bu}$ teoriye göre, cezaların kanunda var olması ve söz konusu suçların işlenmesi durumunda bu cezaların infaz edileceğinin bilinmesi, potansiyel suçlu olarak nitelendirilen ve henüz suç işlememiş ve fakat işleyebilecek olan kişileri korkutmakta ve suç işlemekten alıkoymaktadır ${ }^{75}$. Zira cezanın infaz edilmesi ile diğer insanlara da ibret verilmiş ve toplumsal ahlâk tazelenmiş olmaktadır ${ }^{76}$. Bunun gerçekleşmesi için ise cezaların infazının halka açık alanlarda gerçekleştirilmesi gerektiği ifade edilmiştir. Çünkü 19. yüzyıl ceza kanunlarını etkileyen Feuerbach'ın görüşüne göre, nasıl yapıldığ1 kimse tarafından bilinmeyen, örnek oluşturmayan ve cezalandırılma tehlikesini bilinçlerde güçlü bir biçimde yaratmayan azap çektirmenin herhangi bir anlamı olmayacaktır ${ }^{77}$. Benzer şekilde, Bentham'a göre de cezalandırmama sonucunda "suç işleme yürekliliği " gösterebilecek kişilerin suç işlemesinin yolu açı tutulmuş; cezalandırma sonucunda ise toplumun güvende olması sağlanmış olacaktır ${ }^{78}$. Öyleyse belirtmek gerekir ki toplumsal barışın sağlanması için suç işleyen kişilerin cezalandırılacakları inancının yerleştirilmesi ve bu sayede bireylere, suç işlenmesinin önlenmesine yönelik bir mesaj verilmesi gerekmektedir ${ }^{79}$.

Genel önleme teorisinin benimsenmesi sayesinde, yukarıda açıklanan mutlak teorilerde görülen anlayışın aksine, hâlihazırda suç işlemiş kişiler bir yana, potansiyel suçluların da suç işlemekten alıkonulması mümkün olacak$\operatorname{tır}^{80}$. Önleme teorilerinin önemi, tam da bu noktada kendini göstermektedir ${ }^{81}$. Hatta bu önem daha da ileri götürülmekte ve genel önlemenin, "cezanın tek haklı nedeni" olduğu ileri sürülmektedir ${ }^{82}$.

73 Honig, s. 422-423; Önder, s. 12; Demirbaş, Ceza Genel, s. 576; Koca/Üzülmez, s. 562.

74 Fletcher, s. 30; Öztürk/Erdem, s. 455-456.

75 Dönmezer/Erman, s. 595.

76 Erem, s. 159.

77 Hudson, s. 53.

78 Karakaş Doğan, s. 45.

79 Demirbaş, Ceza Genel, s. 580; Yüce, s. 17-18.

80 Bentham, Ahlak ve Yasama İlkeleri, s. 148-149.

81 Canton, s. 84.

82 Canton, s. 101. 
Ancak genel önleme teorilerine de çeşitli eleştiriler yöneltilmiştir. Buna göre genel önleme teorisi, esas olarak ve yalnızca toplumu korumayı ve korkutmayı hedeflediğinden ceza verilen kişi bakımından insan onuru ile bağdaşmamaktadır. Bunun yanı sıra genel önleme teorisinin, cezaların süresini sınırlandırma noktasında bir ölçü getiremiyor olması, hem çok şiddetli cezalar verilmesi yoluna gidilmesi ile sonuçlanabilmekte hem de cezalandırmanın, devlet için bireyler üzerinde baskı kurmaya yönelik bir araç hâline getirilmesine neden olma riskini taşımaktadır ${ }^{83}$.

\section{2. Özel Önleme Teorisi}

Özel önleme teorisi ise yukarıda bahsedilen üç fonksiyona birden sahip kabul edilmektedir. Zira suç işleyen kişinin sslahını da kapsayan bu teori benimsendiği takdirde dahi ıslahın bir ceza yerine geçemeyeceği aşikârdır. Bir diğer deyişle islah, suçluya verilecek cezanın bir alternatifi olarak değerlendirilmemelidir ${ }^{84}$. Cezanın verilmesindeki amaç, suçlunun ıslahını sağlamayı da kapsamalıdır ${ }^{85}$. Hatta bazı yazarlar tarafindan cezanın amacını açıklayan esas şeyin 1slah olduğu belirtilmektedir ${ }^{86}$. Bunların temel sebebi de toplumun güvende olmasının, suç işleyen kişinin yarattığı riskin yönetilmesi gerekliliğini doğurmasıdır. Toplumun güvende olması da ancak suçlunun 1slahı ile mümkün olacaktır. Çünkü sslah, toplumun sahip olduğu haklar ile suç işleyen kişinin hakları arasındaki çatışmayı ortadan kaldırmayı sağlayabilecektir ${ }^{87}$.

Suç işleyen kişinin bu suçu işlemesinin nedeni irdelendiğinde, suçun nedenlerinin ne olduğuna ilişkin kriminolojik teorilere ${ }^{88}$ değinmekte de

83 Centel, s. 346-347.

84 Canton, s. 123.

85 Islah ifadesine bazı eserlerde rehabilitasyon, bazı eserlerde ise iyileştirme şeklinde yer verilmekte olup bu çalışmada, kullanım alanının yaygınlığı dolayısıyla ve daha kapsayıc1 olduğu düşüncesiyle "1slah" ifadesi tercih edilmiştir. Buna rağmen, kimi yazarlar tarafından 1slahın, "rehabilitative sentencing” şeklinde adlandırılmak suretiyle cezalandırmadaki temel amaçlardan biri hâline getirildiği de görülmektedir. Ayrıca ıslahın, kişinin şahsî özelliklerine göre yerine getirilmesi ile gerekli ve yeterli süre boyunca devam ettirilmesi gerektiği de ifade edilmektedir. Bunun yanı sıra 1slah, özgürlüğün kısıtlanmas1 sonucunu da doğurabilecektir. Bkz. Ashworth, Andrew/von Hirch, Andrew/ Roberts, Julian: Principled Sentencing, Oregon, Hart Publishing, 2009, s. 6-8.

Yarsuvat, s. 98. Keza yukarıda bahsi geçen Toplumsal Savunma Akımı tarafindan ileri sürülen görüş de suç işleyen kişinin 1slahı suretiyle toplumun korunması gerekliliğini kabul etmektedir. Bkz. Tümerkan, s. 62.

Işsktaç, s. 627.

88 Burada yer verilen sınıflandırma dışında etiketleme teorisi, altkültürel teori, kontrol teorisi, firsat teorisi ve öğrenme teorisi olarak beş başlık altında toplayan yazarlar da 
fayda vardır. Zira bu teoriler; biyolojik, psikolojik, sosyolojik ve sosyopsikolojik teoriler olmak üzere dört başlık altında toplanmakta olup ${ }^{89}$ isimlerinden de anlaşıldığ üzere bu teoriler, genel olarak bireylerin kendilerine ya da toplumsal durumlarına ilişkindir. Bu bakımdan önem arz eden bir nokta da bu kişilerin suçlu olarak damgalanıyor olması gerçeğidir ${ }^{90}$. İşte özel önleme teorisi kapsamında suçlunun 1slahının gerçekleştirilmesi de söz konusu damgayı ortadan kaldırma amacina hizmet edecek ve bu sayede suçun önlenmesi için bir adım atılabilmiş olacaktır.

Islah ile caydırıcılığı birbirinden ayıran en önemli faktör; caydırıcılığın sağlanacağı, bir diğer deyişle önlemenin vuku bulacağ 1 ve potansiyel suçlu olarak addedilen kişilerin rasyonel tercihlerine bağlı olarak suç işlediği varsayımında bulunulurken ıslah yaklaşımında, bu kişilerin, yardıma muhtaç kişiler olarak görülmesidir ${ }^{91}$. Bu şekildeki bir yaklaşımın benimsenmesi sayesinde kişiler, iradelerinden bağımsız bir biçimde iyileşmeye zorlanmış olmayacak, aksine davranışlarını daha doğru bir yönde geliştirmek üzere teşvik edilmiş olacaktır ${ }^{22}$. Ayrıca belirtmek gerekir ki bu bakış açısına modern görüşlerde daha sık rastlanmaktadır. Geleneksel nitelikte olan görüşlerde ise suç işleyen kişide yeniden cezalandırılma korkusu yaratmak üzerinden sağlanan caydırıcılık ağır basmaktadır ${ }^{93}$.

Özel önleme teorisi bakımından ceza verilmesi suretiyle ilk olarak suç işleyen kişi korkutulmuş olacak ve böylece o kişinin bir daha suç işlememesi sağlanmış olacaktır ${ }^{94}$. Bu teori bakımından cezalandırmanın ikinci fonksiyonu, suç işleyen kişinin yeniden toplumsal hayata döndürülmesi olup bu husus, cezanın yeniden sosyalleştirme etkisi (resocialization) ${ }^{95}$ olarak adlandırılmaktadır. Son olarak ise suç işleyen kişi, cezalandırıldığı süre boyunca toplumdan uzak tutulmuş olacaktır. Bu sayede toplum, bu kişinin işlemesi

mevcuttur. Bkz. Braithwaite, John: Crime, Shame and Reintegration, Cambridge University Press, 1989, s. 16.

89 Söz konusu teorilere ilişkin ayrıntılı bilgi için bkz. Sokullu-Akıncı, R. Füsun: Kriminoloji, 13. Bası, Beta Yayıncılık, İstanbul, Eylül 2018, s. 163-215.

90 Sokullu-Akıncı, s. 165.

91 Ashworth, Andrew: Sentencing and Criminal Justice, 6. Bask1, Cambridge University Press, 2007, s. 82.

92 Cavadino/Dignan, s. 43.

93 Dönmezer/Erman, s. 596.

94 Fletcher, s. 30.

95 Belirtmek gerekir ki yeniden sosyalleştirme etkisi; topluma kazandırma, zararın azaltılması, normalleşme ve insanı koruma gibi kavramları da kapsayacak şekilde tercih edilen iyileştirme kavramı ile eş anlamlı olarak da kullanılabilmektedir. Bkz Bilgiç, s. 115. 
muhtemel diğer suçlardan da geçici olarak dahi olsa korunacaktır ${ }^{96}$. Eğer bir suçlunun topluma yeniden kazandırılamayacağı değerlendirmesinde bulunuluyorsa da artık bu kişinin zararsız hâle getirilmesi, bir diğer deyişle kişiye ölüm cezası verilmesi mümkün hâle gelecektir ${ }^{97}$.

Özel önleme teorisine de yöneltilen birtakım eleştiriler bulunmaktadır. Bilhassa yeniden sosyalleştirme etkisi dolayısıyla bu teorinin esasında kendi kendini reddettiği belirtilmektedir. Zira böyle bir durumda kişilere ceza verilmesi yerine güvenlik tedbirlerine başvurulması bir zorunluluk arz edecek olup bu teori, bu durumda ne şekilde hareket edilmesi gerektiğini açıklayamamaktadır ${ }^{98}$. Ayrıca bu teorinin, yeniden suç işleme tehlikesi taşımayan faillerin niçin cezalandırıldığını da açıklayamadığ ${ }_{1}$ belirtilmektedir. Zira böyle bir durumda cezaevi, yeniden suç işleme ihtimali olmayan kişiler bakımından adeta bir suç okulu hâline gelmektedir ${ }^{99}$.

\section{Karma Teori}

Mutlak ve nispi teorilere yöneltilen eleştirilerin haklı ve ikna edici olarak değerlendirilmesine rağmen bu teorilerde ileri sürülen görüşlerin aynı zamanda ve bir o kadar yerinde de bulunması dolayısıyla bu noktada ilk olarak karma teorinin neden ileri sürüldüğünü belirtmek gerekir. Kaldı ki söz konusu teorileri birleştirme fikrinin gündeme gelmesi de bu düşünceden hareketle gerçekleşmiştir. Zira mutlak teoriler benimsendiğinde, katı ve amaçsız cezalar verilmesi; nispi teoriler benimsendiğinde ise orantısız ceza verilmesi ya da henüz işlenmemiş suçların da cezalandırılması tehlikesi doğabilecektir ${ }^{100}$.

Karma teorinin ortaya çıkmasının bir diğer nedeni de cezalandırma ile kimi zaman fayda sağlayacak amaçların yerine getirilemeyecek oluşudur. Zira bazı hâllerde cezadan beklenen faydadan ziyade, cezanın ödetici ve acı çektirici amacina başvurmak ön planda tutulabilmektedir ${ }^{101}$. Bu nedenle de söz konusu teoriler birbirleriyle bağdaştırılarak her birinin eleştiriye matuf yönleri adeta törpülenmek suretiyle oluşturulan karma teori ileri sürülmüştür.

Fletcher, s. 30.

Honig, s. 414; Dönmezer/Erman, s. 597; Demirbaş, Ceza Hukuku, s. 581; Karakaş Doğan, s. 46; Dilberoğlu, A. Vedat: "Cezalar ve Güvenlik Tedbirlerinin Amacı ve Niteliği”, Ankara Üniversitesi Hukuk Fakültesi Dergisi, Cilt: 65, Say1: 4, 2016, 1517 1544, s. 1525-1526.

98 Centel, s. 341.

99 Fletcher, s. 31; Öztürk/Erdem, s. 455.

100 Hudson, s. 56.

101 Dönmezer/Erman, s. 594. 
Belirtmek gerekir ki karma teori uyarınca da cezanın esasını temel olarak kefaret oluşturmaktadır. Fakat bu, tek başına yeterli olmayıp cezanın aynı zamanda genel ve özel önlemeyi de sağlaması, bir diğer deyişle hem toplumu koruması hem de suç işleyen kişileri adalete uygun olacak ölçüde suç işlemekten caydırması gerekmektedir ${ }^{102}$. Zira cezanın sadece kefaretten ibaret görülmesi, genel ve özel anlamda yetersiz olabilecektir ${ }^{103}$. Ceza hem geçmişe hem de geleceğe yönelik olmalı, toplumu suçtan korumayı ve suç işleyen kişileri ıslah etmeyi aynı anda amaçlamalıdır. Bu şekilde karma teoriyi savunanlar, mutlak teoriler ile önleme teorilerini bağdaştırmaktadır ${ }^{104}$. Buna göre, mutlak teoriler, adalet ilkesi lehine kişilerin hürriyetini kısıtlamakta; nispi teoriler ise fayda lehine kişilerin hak ve özgürlüklerini geri planda tutmaktadır ${ }^{105}$.

Karma teori uyarınca cezanın kefaret amacı önemli olmakla birlikte, cezanın mümkün olduğunca insanileştirilmesi gerekmektedir. Buradan anlaşlacak husus, işlenen suçun ağırlığıyla verilen cezanın şiddeti arasında bir orantı olması, bir diğer deyişle kusur ve meydana gelen zarar ile orantılı bir ceza verilmesidir ${ }^{106}$. Zira cezaların suça oranla çok ağır olması, iktidarın kötüye kullanılması sonucunu doğuracak; buna karşılık çok hafif olması da toplumsal düzenin bozulması riskini beraberinde getirecektir ${ }^{107}$. Bunun yan1 sıra, ağır cezalara mahkûm edilmiş kişilerin ıslaha 1lımlı yaklaşmaları ihtimali zayıflayacak ve orantısız biçimde ceza verildiğinde cezaların caydırıcılık etkisi azalacaktır ${ }^{108}$. Ayrıca kusur ile sınırlı olmak suretiyle verilecek cezanın, genel ve özel önlemeyi sağlaması amacıyla dahi olsa sınırlarının genişletilmemesi de bir gereklilik olarak karşımıza çıkmaktadır ${ }^{109}$.

Karma teori, oluşturulması aşamasında uygulanan yönteme göre ikiye ayrılmaktadır. Teorinin dış görünüşe göre karma olduğunu ifade edenler, kefaret amacına öncelik vermekte iken; yararcı karma görüş olarak adlandırılan

\footnotetext{
102 Taner, s. 32-33; Yüce, s. 12.

103 Işııtaç, s. 628.

104 Bilgiç, s. 29; Koca/Üzülmez, s. 562.

105 Erem, s. 165.

106 Hofer, Paul J./Loeffler, Charles/Blackwell, Kevin/Valentino, Patricia: Fifteen Years of Guidelines Sentencing: An Assessment of How Well the Federal Criminal Justice System is Acheiving the Goals of Sentencing Reform, Kasım 2004, s. 11; Önder, s. 17 18; Taner, s. 32-33.

107 Işıktaç, s. 628.

108 Hudson, s. 56; Yüce, s. 18-19.

109 Karakaş Doğan, s. 51.
} 
görüşe göre ise cezadan sağlanacak yarar ön planda tutulmalıdır ${ }^{110}$. Benzer yöndeki bir görüşte de "toplumsal fayda ile sinırlı adalet" anlayışı karş1sında, "adaletle sinırlı toplumsal fayda" yaklaşımına rastlanmaktadır" ${ }^{111}$. Buna karşılık bir diğer görüş, cezanın her bir amacına eşit oranda önem atfetmekte ve cezanın amacının kanunda belirtilmediği durumlarda önceliğin ihtiyaca göre belirleneceğini savunmaktadır ${ }^{112}$.

Bir başka sınıflandırma uyarınca ise karma teori; eşitlikçi, önleyici ve ödetici olmak üzere üçe ayrılmaktadır. Eşitlikçi karma teori, farklı teorilerin eşit düzeyde geçerli olduğunu ifade etmekte iken önleyici karma teori, önleme yaklaşımını; ödetici karma teori ise ödetme anlayışını ön planda tutmaktadır ${ }^{113}$.

Nihayetinde belirtmek gerekir ki cezanın amacının, genel bir bakış açısıyla yararcı karma görüşten hareket ederek açıklanması gerektiği de doktrinde ifade edilmektedir. Zira suç oranlarının azaltılması; cezanın amacına ilişkin yukarıda açıklanan görüşlerin, neyin "makul ceza" olduğunun ve olmadığının uygun bir şekilde belirtilerek sınırlandırılması vasıtasıyla mümkün olacaktır ${ }^{14}$. Bir başka deyişle karma görüş, mutlak ve nispi teorilerin sakıncalı yönlerini gidermek bakımından cezanın, adaleti yerine getirmesi ve toplumu korumak adına verilmesi gerektiğini ortaya koymaktadır ${ }^{115}$.

Karma teori benimsendiğinde, cezaların yumuşatılması ve takdiri hafifletici nedenlerin genişletilmesinin yanı sıra, modern ceza hukukunun bir gereği olarak failin kusuruna değer atfedilmesi ve cezanın belirlenmesinde derecelendirmeye gidilmesi de sağlanmış olmaktadır. Ancak kusurluluğun esasını manevi sorumluluğa dayandıran, kişinin yalnızca özgür iradeye ve ayırt etme gücüne sahip olması durumunda cezalandırılabileceğini savunan karma teori, iradenin özgür olduğu varsayımından öteye geçememiş olmasından bahisle eleştirilmiştir ${ }^{116}$. Ayrıca cezanın miktarı ile süresinin de suçun ağırlığına göre belirlenmesi dolayısıyla suç işleme oranı ile tekerrür oranının arttığı iddia edilmiştir ${ }^{117}$.

\footnotetext{
110 Önder, s. 14.

111 Taner, s. 32.

112 Aktaş, s. 22; Karakaş Doğan, s. 50. kullanmaktadır. Bkz. Yüce, s. 10.

114 Hudson, s. 60.

115 Üzülmez, s. 269; Demirbaş, s. 76.

116 Üzülmez, s. 271; Artuk/Gökcen, s. 35.

117 Artuk/Gökcen, s. 36; Karakaş Doğan, s. 51.
}

113 Öztürk/Erdem, s. 457. Bununla birlikte, bu eserde, esasen karma teori kavramı yerine birleştirici teori kavramı kullanılmaktadır. Hakeza Yüce de birleştirici teori ifadesini 
Sonuç olarak ifade etmemiz gerekir ki cezanın fonksiyonları ve cezalandırma ile güdülen amaç, kriminologlar tarafından da günümüze kadar öç alma, suç işlenmesinin önlenmesi, toplumun korunması ve 1slah gibi değişik şekillerde belirtilmiş olmakla birlikte; günümüzdeki eğilimle birlikte artık suç işleyen kişiyi toplumdan uzaklaştırmaktan ziyade, ıslah ve mahkûmu topluma yeniden kazandırma üzerinde durulduğu görülmektedir ${ }^{118}$. Ayrıca yukarıda değindiğimiz teoriler içerisinde modern ceza hukuku bakımından geçerliliğini koruyan ve birçok ülkenin hukuk sisteminde benimsenen teori de karma teoridir ${ }^{119}$.

\section{DEVLET VE ÜTOPYA}

\section{A. Devlet Kavramı}

İlk olarak belirtmek gerekir ki Robert Nozick' in “Anarşi, Devlet ve Ütopya" isimli eserine başlarken yöneltmiş olduğu "Eğer devlet olmasaydl, onu icat etmeye gerek duyulur muydu? Ihtiyaç mı duyulurdu yoksa icat etmek zorunda mı kalınırdı?" şeklindeki sorular, esasen bu çalışmada ele alınan konunun önemini vurgulamaktadir ${ }^{120}$.

Arapça'dan dilimize geçen ve egemenlik yahut iktidar anlamlarına gelen devlet kelimesi yerine Latince "status" kelimesi birçok dilde kullanılmıştır. Kaldı ki Machiavelli de Prens adlı eserinde bu kavramı, insanlar üzerinde emretme yetkisine sahip olmuş veya hâlihazırda sahip olan bütün hâkimiyetler olarak tanımlamış ve bunun ya cumhuriyet ya da krallık şeklinde ortaya çıkacağını ifade etmiştir ${ }^{121}$.

Devleti bir toplum sözleşmesi olarak gören Rousseau, Locke, Grotius, Spinoza gibi filozofların düşünceleri ve tanımları bir kenara, devlet tanımları

118 Hudson, s. 26; Kıdıl, Fahrettin: "Cezalandırmanın Amacı ve "Umut Hakkı" Bağlamında Koşullu Salıverilme Yasakları”, Türkiye Barolar Birliği Dergisi, Sayı: 138, 2018, 39-78, s. 53.

119 Buna karşılık, karma teorinin esasında vadettiği şekilde mutlak teoriler ile nispi teorileri ortak biçimde bünyesinde eritmeyi başaran bir teori olmadığ 1 ifade edilmektedir. $\mathrm{Bu}$ şekilde tüm teorileri bir araya getirip bağdaştıracak şekilde "bütüncül teori" ileri sürülmektedir. Bkz. Maden, s. 58. Bir diğer görüş uyarınca da günümüzde kabul edilen teori, kefaret amacı ile genel ve özel önleme amaçlarını kapsamakta olup bu teori "uzlaştırıcı teori" olarak ifade edilmiştir. Bkz. Demirbaş, İnfaz Hukuku, s. 73.

120 Nozick, Robert: Anarşi, Devlet ve Ütopya, 3. Bask1, İstanbul, İstanbul Bilgi Üniversitesi Yayınlar1, Nisan 2015, s. 31.

121 Şan, Zuhal: "Ütopyalarda Devlet Tasarımı: Platon, More, Campanella", Çukurova Üniversitesi Sosyal Bilimler Enstitüsü, Yayımlanmamış Yüksek Lisans Tezi, Adana, 2010, s. 8-9. 
içerisinde en benimsenmiş olan Jellinek'in sunmuş olduğu "egemenlik gücüyle aslen donatılmış, belli bir toprak parçası üzerinde yerleşik bir millet birliği" şeklindeki tanımdır. Jellinek'in üç unsur teorisine göre devlet; insan, toprak ve egemenlik unsurlarını bir arada bulunduran bir teşkilattır ${ }^{122}$.

Doğal hukuk bakış açısıyla ise devlet, Platon, Cicero ve Aristoteles' in benzer bir biçimde ifade ettiği üzere, insanların ortak çıkarlarlyararları doğrultusunda bir araya gelmek suretiyle oluşturdukları topluluk anlamına gelmektedir ${ }^{123}$.

Oysa Kant, bu düşünürlerden ayrılmakta ve devleti, hukuku yapan ve koruyan olarak tanımlamaktadır. Kant'in ideal devlet şekli olarak ileri sürdügü şekil cumhuriyet olmakla birlikte, ödev etiği anlayışı dahi hukuk ve devlet kavramlarına ışı tutmaktadır. Zira Kant'a göre bir eylemin etik değeri, doğal hukuk etiğinde ifade edildiği üzere, objektif doğal düzende aklın keşfettiği yahut toplum sözleşmesi etiğinde belirtildiği üzere aklın icat ettiği ilkelerden değil; aklın kendi özerk alanı içerisinde zorunlu olarak ulaştığı a priori (deney öncesi) ilkelerden teşekkül etmektedir ${ }^{124}$.

\section{B. Ütopya Kavramı}

"Utopia dediler başlangıçta adıma,

ıssiz olmamdan dolayı

Şimdiyse Platoncu devletin rakibiyim işte,

Ondan daha üstün belki de

(çünkü onun sözcüklerle

Anlattı̆̆ıı ben gerçekleştirdim sadece,

Devlet adamlarlyla, iktidarla ve en iyi yasalarla),

Haklı olarak olmalı adım şimdi Eutopia ${ }^{\text {"125. }}$

Geçmişten günümüze kadar birçok filozofun ve diğer alanlarda düşünceleriyle hem öncü olmuş hem de çeşitli düşünceleri sınıflandırıp derli toplu biçimde ortaya koymuş düşünürlerin cevaplamaya çalıştığ 1 temel bir soru,

Gözler, Kemal: Devletin Genel Teorisi, Bursa, Ekin Kitabevi, 2018, s. 4.

Şan, s. 10.

Şan, s. 11-12.

Ütopya'da, Yunanca "boş konuşan kişi” anlamına geldiği ifade edilen Anemos adındaki hayalî bir şaire ait olduğu söylenen bu şiirin gerçek yazarı bilinmemektedir. Ancak şiirin Thomas More'a ait olması ihtimalinin yüksek olduğu düşünülmektedir. Bkz. Dumlu, Hediye: “Thomas More'un Ütopya'sında Adalet Kavrayışı”, Ege Üniversitesi Sosyal Bilimler Enstitüsü, Yayımlanmamış Yüksek Lisans Tezi, 2014, s. 2. 
devletin neden ve nasıl ortaya çıktığı sorusudur. Hatta bundan evvel, yukarıda da belirtildiği üzere, devletin gerekli olup olmadığı dahi sorgulanmıştır. $\mathrm{Bu}$ noktada da ütopyaların ortaya atılması söz konusu olmuştur. Zira düşünürler, devletin ortaya çıkışını meşru bir zemine oturtma ihtiyacının kısmen dahi olsa giderilmesi ile birlikte, artı ideal olan devleti aramaya koyulmuşlardır. Yalnız bununla da kalmamış, idealin belki de tam olarak zıddı diye nitelendirebileceğimiz ve gerçekleşmesinden korku duyulan devlet tasarımlarını, bir diğer deyişle distopyaları da ortaya koymuşlardır.

Çalışmamız kapsamında ele almayı amaçladığımız ütopyalara ilişkin değerlendirmeye geçmeden evvel, ütopya kavramına kısaca değinmekte fayda bulunmaktadır. İlk olarak belirtmemiz gerekir ki "ütopya" denildiğinde esasen iyi anlamda ütopya kavramı akla gelmekte ise de bu kavram, bir üst kavram olarak addedilmelidir. Zira yukarıda yer verilen şiirden de anlaşıldığı üzere, Türkçe'de her ikisi de ütopya olarak anılmakta olmasına rağmen, Latince'deki outopia/eutopia kavramı, hem "olmayan yer" kavramını ifade etmek suretiyle iyi anlamda ütopyayı hem de distopya olarak adlandırdığımız korku duyulan ütopyayı kapsamaktadır.

Yukarıda ifade ettiğimiz hususu destekler biçimde Kumar, ütopyanın hem hiçbir yerde olmayan yer (outopia) hem de iyi olan yer (eutopia) anlamına geldiğini ve bu şekilde, mümkün olmayan ve fakat insanın orada bulunmak için heves ettiği bir dünya olduğunu ifade etmektedir ${ }^{126}$. Bununla birlikte, ütopyaların tamamen kurgusal olduğunu ifade etmemiz de mümkün değildir. Zira her ne kadar bir kurgu şeklinde oluşturulmuş dahi olsa ütopyalar, açık bir biçimde teoride kalmamaktadır ${ }^{127}$. Burada ifade edilmek istenen, gerçekleşmesinden korku duyulan bu kurgunun, aslında gerçek hayatta da karşılaşılabilen birtakım hususları bünyesinde barındırıyor olmasıdır.

Öyleyse ütopya kavramının olumlu anlamıla ideal toplum ve devlet tasarımları; olumsuz anlamıyla bir diğer deyişle distopya kavramıyla ise korku duyulan bir devlet tasarımı, totaliter ve baskıcı toplumlar ifade edilmektedir. Distopyalar; iyilik, doğruluk, güzellik, adalet ve mutluluk taşıyan ütopyaların aksine, karamsar olmaktan da öte, gerçekçi bir tedirginlik ile dünyaya yaklaşmaktadır. Ayrıca bu evren içerisinde insanı mutlu edecek şeylerin, her geçen gün daha da azaldığı ya da azalacağı konusunda bir öngörüde bulunmaktadır ${ }^{128}$.

\footnotetext{
126 Kumar, Krishan: Ütopyac1lık, (Çev.: Ali Somel), İmge Kitabevi, 2005, s. 9.

127 Young, Peter: "The Importance of Utopias in Criminological Thinking", The British Journal of Criminology, Cilt: 32, Sayı: 4, 1992, 423-437, s. 428. 


\section{IV. ÜTOPYALARIN DEĞERLENDİRILMESİ}

\section{A. George Orwell: Bin Dokuz Yüz Seksen Dört}

Öncelikle belirtmek gerekir ki Orwell, yarattığı bu dünyadaki iktidarı, "acı çektirmek ve küçük düşürmek, insanın kafasını parçalamak ve istenen biçimde bir araya getirmek" olarak betimlemiştir. Söz konusu dünya, "yaşamanın amacinı zevk kabul eden aptal ütopyaclların tam tersi bir yer... Korkunun, acının, işkencenin dünyası. Kendini geliştirdikçe daha da acımasızlaşan" bir yer olarak tasvir edilmiştir ${ }^{129}$.

Orwell'in bu eserinde iktidar kavramını temsil eden Parti, insanı asla yalnız bırakmaz ve her an onunladır. Bütün parti üyelerinin evlerinde ve iş yerlerinde onları gözetleyen bir tele ekran mevcuttur. Her an gözetlendiğini ve en ufak bir yanlışta dahi uyarılıp cezalandırılacağını bilen bir ruh hâli içerisinde bulundurulan bir kitle söz konusudur. En ufak bir tedirginlik bile "düşünce suçlusu" olmak için yeterlidir. İnsanlar asla partinin ve onun başındaki hayalî karakter olan Büyük Birader' in gözünden kaçamaz. Yaşamak demek, yalnızca partinin buyruklarına uymak ve onun ilkelerini benimsemek anlamına gelmektedir. Partinin, ülkenin her yerinde yazılı olan en temel ilkesi şu şekildedir: "Savaş barıştır, özgürlük köleliktir, bilgisizlik kuvvettir" ${ }^{\prime 30}$.

Parti üyesi herkes, partinin belirlediği ilkeleri benimsemek zorundadır. Parti asla onların düşünmesine izin vermez. Hiç kimse söylenenler dışında bir şey yapma hakkına sahip değildir. Kendilerine verilenle yetinmeleri gerektiğini benimsetmek, bu iktidarın temel ilkelerinden birisidir. İktidar, insanı; düşünceden eyleme, geçmişten geleceğe, doğumdan ölüme kadar kontrol altında tutmayı amaçlamaktadır. Nitekim bu amacını yerine de getirmektedir. Kitapta birkaç defa belirtildiği üzere, böyle bir anlayışın hâkimiyeti altında iken insan olarak kalmak oldukça zordur. Zira bu durum, dayatmadan çok daha öte, adeta ele geçirme anlamına gelmektedir. Söz konusu olan öyle bir egemenliktir ki insanların zihinlerinin içine kadar hâkim olmuştur ve onlara düşünmeleri gerekeni bile kendisi söylemektedir.

Orwell'e göre televizyonun yapımı ve hem alıcı hem de verici olarak kullanılmasını sağlayan teknik gelişmeler, özel hayata son vermiş ve gözetlenmesi gereken herkesin aralıksız bir biçimde denetlenmesini ve aynı zamanda sürekli bir resmî propaganda altında tutulabilmesini mümkün

129 Orwell, George: Bin Dokuz Yüz Seksen Dört, Can Yayınları, Mart 2008, s. 233.
Orwell, s. 11. 
kılmıştır. Bu sayede herkesin devletin isteklerine boyun eğmesi ve her konuda düşünsel birliğin oluşması da temin edilmiştir.

Kişilerin düşünmelerinin dahi imkânsız hâle gelişini, eserde geçen şu cümleler çarpıcı bir biçimde ortaya koymaktadır: "Bir tele ekran görüş alanı içinde ya da genel bir yerde, düşüncelerini serbest akışına bırakmak hiç doğru değildi. En ufak bir şey; sinirsel bir tik, kederli bir görünüş, kendi kendine bir şeyler murıldanma huyu, olağan dışılık ya da bazı şeylerin gizlendiği kanısını uyandırabilecek her şey sizi ele vermeye yetebilirdi. Yüzünüze uygunsuz bir anlatım vermek ceza gerektirecek bir suç sayılırdı "131.

Kitap boyunca mütemadiyen tekrar edildiği üzere, bir gün yakalanmak ve işlenen düşünce suçunun bedelini ödemek kaçınılmaz sondur ${ }^{132}$. Hatta şu cümle, ceza hukukunun temel ilkelerine ve güvencelerine aykırılığın boyutunun ne denli büyük olduğunu açıkça ortaya koymaktadır: "Düşünce suçu ölüm tehlikesi yaratmaz, düşünce suçunun kendisi ölümdür",133.

1984'te kanunların durumuna bakıldı̆̆ı zaman, örneğin alelade bir dükkâna girmek ya da günlük tutmak gibi eylemler bile fark edilmesi durumunda yirmi beş yıl hapis ya da zorunlu çalışma kampına gönderilme cezasına ve hatta ölüm cezasına neden olabilecektir. Oysa bunlar, kanuna aykırı değildir. Zira artık kanun diye bir şey bulunmamaktadır. Öyleyse kanuna aykırılık da söz konusu olmayacaktır ${ }^{134}$. Bu husus, şu şekilde ifade edilmiştir: "Okyanusya'da yasa yoktur. Saptandikları zaman ölüme neden olabilecek düşünce ve davranışlar resmen yasaklanmamıştır. Sonu gelmeyen temizlikler, tutuklamalar, işkenceler, idamlar, işlenmiş suçları cezalandırmak için değil, gelecekte bir gün suç işleyebilecek kişileri ortadan kaldırmak içindir" $" 135$.

Yukarıdaki ifadeden yola çıkarak, bir an için önleme amacının da yansımaları varmış gibi görünüyor dahi olsa, genel olarak 1984 distopyası içerisinde gerçek manada genel yahut özel önleme amacından bahsedebilmek mümkün değildir. Önleme gibi bir amacın güdülmediğini şuradan hareketle tespit etmek mümkündür: "Sürekli hafif bir acı içerisinde olmasına özen gösteriyorlardı ama istedikleri derin bir acı değildi. Yüzünü tokatllyor,

131 Orwell, s. 60.

132 Bu husus şu şekilde ifade edilmiştir: "Suç oluşturabilecek tek bir sözcük yazmamış olsa da yine de tüm suçları içine alan bir suç işlemek mümkündür: düşünce suçu. Bir süre saklanmak mümkün olsa dahi önünde sonunda yakalanacaksınızdır. Bunu engelleyemezsiniz.” Bkz. Orwell, s. 94.

133 Orwell, s. 32.

134 Orwell, s. 13.

135 Orwell, s. 185. 
kulaklarını büküyor, saçını çekiyor, onu tek ayak üzerinde durdurtuyor, tuvalete gitmesine izin vermiyor, gözleri kan içinde kalıncaya dek gözüne beyaz ışık tutuyorlardı. Bunlardaki amaç, onu aşağılamak, tartışma ve neden bulma konusundaki direncini ve yeteneğini kırmaktı. Gerçek silahları saatlerce süren sorgulamalard ",136. Zira partinin cezalandırmayla güttüğü ve burada belirtilmiş olan amaç, açıkça anlaşılmaktadır ki somut olaydaki faili ya da toplumdaki diğer bireyleri suç işlemekten alıkoymak değildir. Tüm bunlar bir arada değerlendirildiğinde, kişilere acı çektirmek üzerine kurgulanmış bu cezalandırma sisteminde cezalandırmanın amacına ilişkin hangi teorinin benimsendiği sorusuna, bunun ancak mutlak teori olabileceği şeklinde cevap verilmesi mümkündür.

Yukarıda değinilen hususlar bir kenara, bu iktidarın ülkesinde herhangi bir şekilde insan ilişkisi ya da insanlar arasında sevgi, saygı ve güven gibi duygulara da yer yoktur. İktidarın bu şekilde birbirine güvenmeyen insanlar yaratması, kendi çıkarlarına hizmet etme amacını taşımaktadır. Zira burada duyulması gereken tek bir sevgi, sayg1 ve güven vardır; o da Büyük Birader'e yönelik olmak durumundadır.

Burada son olarak belirtmemiz gereken husus, 1984 'te özel mülkiyetin kaldırılması gerektiğinin ifade edilmiş olmasıdır. Ancak buradaki amaç, servet ve ayrıcalığı Ütopya'da olduğu gibi ortadan kaldırmak değil, aksine onu ortak mülkiyet konusu hâline getirir gibi görünerek en kolay biçimde savunmak ve belli bir kesime özgülemektir.

Sonuç olarak, bu bölümde anlatılanları yukarıda açıklanan görüşler doğrultusunda değerlendirdiğimizde, tipik bir distopya örneği olan 1984'te yer alan mutlak teorilere ilişkin birçok ayrıntı dolayısıyla, distopyalardaki cezalandırmanın amacına ilişkin anlayışın, mutlak teorilerle açıklanabileceğini söylememiz mümkündür.

\section{B. Thomas More: Ütopya}

Ütopya'nın birinci kitabında yer alan güncel politikalara ilişkin tartışmalarda İngiltere'deki ceza sisteminin eleştirildiği görülmektedir. Hırsızlık yapan fakir bir kişinin, bu suçu nedeniyle ölüm cezasına mahkûm edilmesini adil olmadığ gerekçesiyle eleştiren ve kendisi de bir hukukçu olan More, söz konusu adaletsizliklerin ve haksız uygulamaların kanunların gölgesine sığınılarak gerçekleştirildiğini ifade etmektedir ${ }^{137}$. Cinayet ve hırsızlık gibi

136 Orwell, s. 212.

137 More, Thomas: Ütopya (Çev.: Necmiye Uçansoy), İstanbul, Bordo Siyah Yayınları, 2007, s. 31 . 
aynı ağırlıkta olmayan iki ayrı suç için de ölüm cezasının öngörülmüş olması ile hem haksızlık yapıldığını hem de caydırıcı olmaktan uzaklaşıldığını belirtmektedir ${ }^{138}$. Buradan hareketle de More, toplumsal savunma akımına mensup kabul edilmekte ve ölüm cezası yerine hürriyeti bağlayıcı cezalar uygulanması gerektiğini ifade etmesi bakımından da hümanizm akımı etkisi altında olduğu ileri sürülmektedir ${ }^{139}$.

More'a göre uygulanan cezaların, halkın yararını adaletle uzlaştırması gerekmektedir. Bir diğer deyişle cezalar, hem kendi içinde adil olmalı hem de toplum için faydalı olmalıdır ${ }^{140}$. Bununla birlikte, zengin azınlığın çıkarlarını korumaya hizmet eden hukuk ve insanlar arasındaki eşitsizliği haklı gösteren kanunlar, adaletsizliği meşrulaştırmanın bir amacı hâline gelmekte ve "ortak iyi" anlayışının bireysel çıkarlar tarafından yıpratılmasına neden olmaktadır. Buna sebep olan en büyük şey de özel mülkiyet olarak ifade edilmiştir ${ }^{141}$. Bu nedenle birinci kitapta özel mülkiyetin ortadan kaldırılmas1 gerektiği, aksi takdirde zenginliğin eşit ve adil bir dağılımının mümkün olmaması bir yana, milletin iyi bir biçimde yönetilmesinin de söz konusu olamayacağ belirtilmektedir $^{142}$. İkinci kitapta da ortak mülkiyete geçilmesi gerektiğini ifade etmek suretiyle bu şekilde oluşturulmuş bir toplum tasar1mını ortaya koymaktadır. Özel mülkiyetin olmadığının en büyük göstergesi, Ütopya'da hiçbir kapının kilitlenmemesidir. Böylece herkesin her yere girmesini mümkün kılmak suretiyle hiçbir şeyin hiç kimseye ait olmaması sağlanmaktadır ${ }^{143}$.

Ütopyalıların erdemleri, "çllgınlıklara yer vermeyen bir devlet düzeni içinde gördükleri eğitimden" kaynaklanmaktadır. Ütopya'da öğretmenler, çocuklara yalnız bilgi vermekle kalmamakta, onlara, her şeyden önce doğru dürüst dü̈sünmesini öğretmektedirler. Oysa yukarıda ele alındığı üzere, 1984 'te bunun tam tersi bir durum söz konusudur. Zira düşünme şeklindeki eylem dahi bizatihi suç teşkil etmektedir.

\footnotetext{
138 Stillman, Peter Gordon: "Justice, Crime, and Punishment in More's Utopia" Pablo Guerra (Ed.) Utopía: 500 años, Ediciones Universidad Cooperativa de Colombia, 2016, 367-379, s. 369; More, Ütopya, s. 31, 42.

139 Yarsuvat, s. 92.

140 More, Ütopya, s. 31.

141 More, Ütopya, s. 67; Dumlu, s. 94-95.

142 More, Ütopya, s. 68.

143 Bu husus Ütopya'nın İngilizce baskısında şu şekilde ifade edilmektedir: "give admission to anyone, so that nothing at all is private". Bkz. More, Thomas: Utopia, Broadview Press, Peterborough, 2010, s. 62.
} 
Ütopyalılar, iyi ahlâkın ancak doğru düşünceden doğabileceğini bildikleri için tek amaçları, yalnız yöneticiler ile bilimle uğraşanların değil, tüm yurttaşların gerçek anlamda aydın olmasıdır. Ütopyalılar, sırf bu amaç uğruna gereksiz üretim yapmaktan kaçınıp çalışma saatlerini ellerinden geldiği kadar kısa tutmaktadırlar. Çünkü onların değer yargılarına göre, "gerçek mutluluk, bilim ve sanatla zenginleşen insan düşüncesinin özgürce gelişmesi" nden başka bir şey değildir ve yönetim biçimlerinin daha iyi olmasının da halkının daha mutlu olmasının da esas nedeni, yeniliklere ve bilgiye zihinlerini daima açık tutmalarıdır ${ }^{144}$.

Dikkat çeken bir diğer husus, More'un, kitabın geneli boyunca kendi çağının yönetimini eleştirmekte oluşu ve bu yönetimdeki eksikliklerin nasıl düzeltilebileceğini gösterme çabasıdır. Ayrıca devletin bir kurum olduğunu ve bu kurum içinde alınan kararların kişisel olmadığını da senato kavramıyla vurgulamaya çalışmaktadır. Zira bu senatonun bir araya geldiği toplantılar dışında karar alınması yasaklanmışıırı ${ }^{145}$. Ayrıca bu toplantılarda da bir konu gündeme getirileceği zaman o konunun derhal konuşulması değil, bir sonraki toplantıya bırakılması şeklindeki prensip kabul edilmiştir. Böylece ivedilikle verilecek bir karar dolayısıyla düşünülmeden karar verilmesinin ve ardından kararından dönmemek adına, haksız yere de olsa, söz konusu kararda diretilmesinin önüne geçilmeye çalışılmaktadır ${ }^{146}$. Bu noktada, 1984 ile ortak bir yön söz konusuymuş gibi görünse de 1984'teki kararların kolektif biçimde alınması ve bireysel karar verilmeyişinin esasen göstermelik oluşu ile belirli bir azınlık kitlenin çıkarlarına hizmet etmesi, Ütopya'daki durum ile farklılık arz etmektedir.

Ütopya'da herkesin kendi kendini savunması daha doğru sayıldığı için mahkemelerde avukat bulunmamaktadır. Avukatların olmayışı ve kanun sayısının azlığı sayesinde, çeşitli kanunî hileler ve kanunların kötü amaçlar uğruna kurnazca yorumlanması da önlenmiş olacaktır ${ }^{147}$.

Ütopya'daki adaletin bir diğer ilginç yanı da bir suçu doğrudan işlemek ile yalnızca tasarlamak arasında hiçbir ayrım gözetilmemesi ve bir suçu işlemeyi tasarlayanların, o suçu işlemiş gibi cezalandırılmasıdır. Ütopyalılar bu konuda, "Kötülük yapmak isteyen, sadece karşısına bir engel çıkttğı için bu kötülüğü yapmamışsa niçin suçlu sayılmasın?" ş̧eklinde bir düşünceye sahiptirler. Buna benzer bir durum, 1984'te de söz konuş olup "Partiye

\footnotetext{
144 More, Ütopya, s. 71.

145 More, Ütopya, s. 81.

146 More, Ütopya, s. 82.

147 More, Ütopya, s. 66.
} 
düşman olduğu doğruydu ve Partinin görüşüne göre, düşünce ve eylem arasinda fark yoktu" cümlesinden de bu durum açıkça anlaşılmaktadı1 ${ }^{148}$.

Ütopya'da mevcut olan düzende; eğitilmelerine, geçim dertlerinin olmayışına, toplumun onlara verdiği güven duygusuna ve mevcut olan az say1daki kanunların doğruluğuna rağmen yine de suç işleyen kişiler, cezaların en ağırı olarak nitelendirilen cezaya mahkûm edilir ve köle olurlar. Suçluluklarının utanç verici simgesi olarak da boyunlarında altın zincirler taşıyan ${ }^{149}$ bu kölelere verilen ceza, yenilecek hayvanları kesip yıkamak gibi zahmetli, iğrenilen ve ağır bulunan işleri yapmaları ve başkalarından daha fazla çalışmalarıdır ${ }^{150}$. Ele geçirdikleri savaş tutsaklarına dahi köleliği fazla onur kırıcı bir ceza olarak gören Ütopyalılar, yabancı ülkelerde suç işleyen kişileri de ara sıra köle olarak satın alırlar ${ }^{151}$. Ütopya, ideal bir toplum düzeni olarak kurgulanmış olmasına rağmen kölelik kurumuna yer verilmesi bakımından eleştirilmektedir $^{152}$.

Ütopyalılar, biri suç işledi diye onu öldürmenin, hem bu kişiye haksızlik olduğuna, hem de topluma herhangi bir yarar sağlamadığına inanmaktadırlar. Köle durumuna düşüp özgürlügüünden yoksun kalmak ise bir suçlu için ölümden beter bir ceza anlamına gelmektedir. Üstelik bir köle hem topluma yararlı olup başkalarına aynı suçu bir daha işlememesi bakımından örnek olmaktadır hem de günün birinde doğru yola gelmesi, iyileşmesi ve düzgün bir insan olması imkânı bulunmaktadı1 ${ }^{153}$. İşte bu yüzden bir köle, artık pişman olduğunu ve iyiliğe doğru yöneldiğini davranışlarıyla kanıtlarsa ya başkanın ya da halkın isteği üzerine kölelikten kurtulabilir. Zira hiçbir köle, özgürlüğe kavuşma ihtimali hususunda umutsuzluğa sevk edilmeme$\operatorname{lidir}^{154}$. Değinilen tüm bu hususlardan, Ütopya'daki cezalandırmaların, özel ve genel önleme amaçlarını bünyesinde barındırdığı ve dolayısıyla nispi teorilerin etkisi altında olduğu anlaşılmaktadır.

Bununla birlikte, bir türlü iyileşme göstermeyen ve sürekli suç işleyen köleler ölüm cezasına mahkûm edilmektedir. $\mathrm{Bu}$ husus, mutlak teoriler

\footnotetext{
148 Orwell, s. 213.

149 Bunun sebebi, Ütopya'da, esasında maddî değeri yüksek olan altın gibi değerli şeylere dahi çocuklar için oyuncak olarak kullanılması suretiyle değer atfedilmemesi ve bunlara verilen değerin de aşağılayıcı görülmesidir.

150 More, Ütopya, s. 90.

151 Stillman, s. 373-374.

152 Avineri, Shlomo: "War and Slavery in More's Utopia", International Review of Social History, Cilt: 7, Sayı: 2, 1962, 260-290, s. 260.

153 More, Ütopya, s. 46.

154 More, Ütopya, s. 47.
} 
bakımından cezalandırmanın bir amacının da suçlunun toplumdan tasfiye edilmesi olduğundan yola çıkarak bir değerlendirmeye tâbi tutulabilir. Buna göre, suçlu için uslandırıcı amacın gerçekleşmesinin imkânsız hâle gelmesi üzerine, cezalandırmanın başlıca amaçlarından biri olan toplumun korunmasinın devreye sokulması verisinden hareket ederek bu hususu mutlak teoriler ile bağdaştırmamız mümkündür. $\mathrm{Bu}$ durumda da suçlunun ya toplumdan uzaklaştırılması ya da tamamıyla tasfiyesi, bir diğer deyişle ölüm cezasına hükmedilmesi yoluna gidilecektir ${ }^{155}$. Buradan yola çıkarak Ütopya'da, cezalandırmanın amacı bakımından hem mutlak teorileri hem de önleme teorilerini birbirleriyle uzlaştırıp bağdaştırarak bünyesinde taşıyan karma teorinin benimsendiği sonucuna ulaşmaktayız.

\section{SONUÇ VE DEĞERLENDİRME}

$\mathrm{Bu}$ çalışmanın konusunun seçilmesinde, cezalandırmanın amacının yalnızca var olan devletlerde değil, aynı zamanda olması ya da olmaması gereken devlet tasarımlarında da ne şekilde temellendirildiği sorusundan hareket edilmiştir. Bu sorunun cevaplanması ile gerek hâlihazırdaki kanunların uygulanması gerek yeni kanunların yapılması aşamalarında, şayet bu kanunlar suç ve ceza öngörüyorsa güdülecek amacin ne olduğunun unutulmaması gerektiğini ortaya koymak amaçlanmaktadır. Zira cezalar öngörülür ya da uygulanırken olması gereken ve istenen bir devletteki gibi mi yoksa olması istenmeyen ve hatta olmasından korku duyulan bir devletteki gibi mi hareket edileceği, hem doğurması muhtemel sonuçlar hem de ceza hukukunun birçok temel ilkesi bakımından büyük bir önem taşımaktadır.

Söz konusu amaca ulaşmak bakımından bu çalışmada, ilk olarak cezalandırma yetkisi ve bu yetkinin kaynağı ile cezanın meşruiyeti kısaca açıklanmaya çalışılmışırı. Daha sonra ise cezalandırmanın amacına ilişkin teorilerin ne olduğuna ilişkin açıklamalarda bulunulmuştur. Söz konusu teorilerden ilki mutlak teoriler olup bu teorilere göre cezalandırmanın kendisi, bizatihi amaç olarak görülmekte ve geçmişe yönelik olduğu kabul edilmektedir. Ayrıca bu amaç, faile fiilinin bedelini ödetmek (kefaret) ya da adalet duygusuna hizmet edecek biçimde cezayı hangi koşul altında olursa olsun yerine getirmek şeklinde kendisini göstermektedir. Zira mutlak teoriler uyarınca cezalandırma vasıtasıyla korunması gereken, bu cezaya mahkûm edilen kişi değil, yalnızca toplum olmalıdır. Toplumun korunması için de mahkûmun toplumdan uzaklaştırılması gerekmektedir. Ayrıca bu teoriler uyarınca

155 Honig, s. 414; Dönmezer/Erman, s. 597; Demirbaş, Ceza Hukuku, s. 581; Karakaş Doğan, s. 46; Dilberoğlu, s. 1525-1526. 
mahkûmun iyileştirilmesi de cezalandırma ile güdülen amaçlar arasında yer almamaktadır.

Cezalandırmanın amacına ilişkin teorilere yer verilen kısımda ikinci olarak ele alınan ise nispi teorilerdir. Genel önleme ve özel önleme olarak ikiye ayrılan nispi teoriler bakımından ceza, geleceğe yönelik olup bir araç olarak nitelendirilmektedir. Genel önleme teorisine göre cezalandırmanın amac1, toplumdaki diğer bireylerin suç işlemesinin önüne geçmek suretiyle caydırıcılığın sağlanmasıdır. Özel önleme teorisi uyarınca ise cezalandırmanın amacı, doğrudan kişinin kendisini suç işlemekten alıkoymak ve o kişinin ıslah edilmesi vasıtasıyla topluma yeniden kazandırılmasını sağlamaktır.

Burada belirtmek gerekir ki genel önlemeyi sağlayabilmek için dahi olsa, cezaların; toplumu kontrol altında tutmaya yönelik bir araç olarak kullanılması, en ağır hukukî yaptırım olması nedeniyle temel hak ve özgürlüklere telafisi imkânsız zararlar verebilecektir. Bu bakımdan bilhassa modern ceza hukukunda, cezaların ödetme amacı taşıması anlayışı büyük oranda terk edilmiştir. Önleme amacına göre ise verilecek ceza, failin topluma yeniden kazandırılmasını sağlayabilecek şekilde ve kusuru ile orantılı olacak ölçüde belirlenmelidir. Zira önleme teorileri, cezayı, ancak bu şekilde yerine getirilmesi koşuluyla benimsemektedir. Ayrıca uygulamadan anlaşıldığı ve yapılan kriminolojik araştırmalarla da desteklendiği üzere, cezaların korkutucu ve caydırıcı bir etkiye sahip olmasının, ağır olması ya da şiddet içermesi ile sağlanamayacağı hususunda tereddüt bulunmamaktadır.

Nihayetinde belirtmeliyiz ki cezalandırmanın kefaret yönünü tamamen yadsımak mümkün değildir. Ancak bu, özellikle de günümüzde, cezalandırmayı tek başına haklı hâle getirmemektedir. Kaldı ki her döneme ve ülkeye göre farklılık gösterecek bir adalet anlayışıyla da hareket edilmemelidir. Zira bu şekilde farkl1lık arz eden bir noktadan hareket ederek mutlak ve genel geçer bir ölçünün ortaya konulması mümkün olmayacaktır.

Çalışmanın son bölümünde ise birer örnek olarak seçilen Thomas More'un Ütopya isimli eseri ile George Orwell'ın 1984 isimli eseri değerlendirilmiştir. Söz konusu eserlerde yer alan ve cezanın amacına ilişkin olduğu tespit edilen hususlar, çalışmada yer verilen teoriler çerçevesinde ele alınıp bu bakımdan birbirleriyle karşılaştırılarak analize tâbi tutulmuştur. $\mathrm{Bu}$ analiz sonucunda, Ütopya' da karma teorinin; 1984'te ise mutlak teorinin hâkim olduğu kanaatine varılmıştır. Zira 1984 'te açıkça belirtildiği üzere, cezalandırmaya başvurulması ile güdülen esas amaç, gelecekte bir gün suç işleyebilecek kişileri ortadan kaldırmaktır. Ütopya'da bu noktaya ilişkin 
argümanlar değerlendirildiğinde ise görülmektedir ki öngörülen cezalar, hem adalet duygusuna hitap etmeli hem de toplumun yararına olmalıdır.

Cezalandırmanın amacına ilişkin olarak her iki kitapta yer alan argümanların yanı sıra dikkat çeken bir diğer husus da Ütopya'da yer alan demokratik bir toplum modeline ilişkin motiflerdir. Zira bu eserde, içinde bulunulan dönemin yönetim biçimi eleştirilmekte ve yönetimdeki eksikliklerin nasıl düzeltilebileceğine ilişkin öneriler de ortaya konulmaktadır. $\mathrm{Bu}$ noktada vurgulanan husus, devletin bir kurum olduğu ve bu kurum içinde alınan kararların da kişisel nitelikte olmadığıdır. Kaldı ki Ütopya'da bir senato mevcut olup senatonun bir araya geldiği toplantılar dişında karar alınması mümkün olmadığ gibi, bu toplantılarda bir konu gündeme getirileceği zaman da o konu derhal görüşülmeyecek, görüşme sonraki toplantıya bırakılacaktır. Bu sayede, sonrasında geri dönülmesi zor olan bir kararın ivedilikle verilmesinin önüne geçilmiş olacaktır. Bu durum, ilk bakışta 1984 ile ortak bir nokta gibi de görünse, 1984'te kararların kolektif biçimde alınması ve bireysel karar verilmeyişinin görünüşte olması ve esasında belirli bir zümrenin çıarlarına hizmet ediyor olması dolayısıyla Ütopya'daki durum ile farkl1lik arz etmektedir.

Sonuç olarak 1984'te, modern ceza hukuku ile hiçbir surette bağdaşmayacak bir biçimde, kefaret teorisinden hareket eden mutlak teorinin kabul edildiği ve ayrıca böyle bir yönetim altında kişilere sağlanması gereken asgarî düzeydeki güvencelerin tanınmadığı, hatta bu güvenceler bir yana, insan olmanın gereklerinin dahi tamamıyla yadsındığ 1 tespit edilmiştir. Buna karş1lık Ütopya'da, mutlak ve nispi teorileri eklektik bir biçimde ele alan karma teorinin kabul gördügünü belirtmek mümkündür. Bu bakımdan günümüzde de devletler tarafından, modern ceza hukuku anlayışına uygun olup devletin yönetim biçimi açısından da tercih edilebilecek niteliği haiz olan Ütopya'da olduğu gibi, cezalandırmanın amacına ilişkin olarak karma teorinin benimsenmesinin yerinde olduğu sonucuna varılabilecektir. 


\section{KAYNAKÇA}

Aktaş, Sururi: "Cezalandırmanın Amacı Üzerine", Erzincan Üniversitesi Hukuk Fakültesi Dergisi, Cilt: XIII, Sayı: 1-2, 2009, 1-25.

Altınok Villemin, Derya: "Ceza Kavramı, Nitelikleri, Amacı ve Sınıflandırılması", İstanbul Kültür Üniversitesi Hukuk Fakültesi Dergisi, Cilt: 16, Say1: 2, 2017, 149-162.

Artuk, M. Emin/Gökcen, Ahmet: Ceza Hukuku Genel Hükümler, 12. Bask1, Ankara, Adalet Yayınevi, 2018.

Ashworth, Andrew/von Hirch, Andrew /Roberts, Julian: Principled Sentencing, Oregon, Hart Publishing, 2009.

Ashworth, Andrew: Sentencing and Criminal Justice, 6. Bask1, Cambridge University Press, 2007.

Avineri, Shlomo: "War and Slavery in More's Utopia", International Review of Social History, Cilt: 7, Say1: 2, 1962, 260-290.

Beccaria, Cesare: Suçlar ve Cezalar Hakkında (Çev.: Sami Selçuk), İmge Kitabevi, 2013.

Bentham, Jeremy: Ahlak ve Yasama İlkeleri, (Çev.: Ömer SaruhanlığluUğur Kâşif Boyacı), İstanbul, Litera Yayıncılık, 2017.

Bentham, Jeremy: Punishment and Deterrence, Oxford, 1998.

Bilgiç, Şükrü: Hapsedilme, İyileştirme ve Yeniden Suç İşleme, Ankara, Vadi Yayınları, Ekim 2012.

Braithwaite, John: Crime, Shame and Reintegration, Cambridge University Press, 1989.

Byrd, B. Sharon: "Kant's Theory of Punishment: Deterrence and its Threat, Retribution in its Execution", Law and Philosophy, Netherlands, Kluwer Academic Publishers, 1989, 151-200.

Canton, Rob: Why Punish? An Introduction to the Philosophy of Punishment, Palgrave, 2017.

Cavadino, Michael/Dignan, James: The Penal System, 4. Bask1, Sage Publications, 2007.

Centel, Nur: "Cezanın Amacı ve Belirlenmesi”, Turhan Tufan Yüce'ye Armağan, İzmir, Dokuz Eylül Üniversitesi Yayınları, 2001, 337-372.

Demirbaş, Timur: Ceza Hukuku Genel Hükümler, Güncellenmiş 14. Bask1, Ankara, Seçkin Yayıncılık, 2019.

Demirbaş, Timur: İnfaz Hukuku, 6. Baskı, Ankara, Seçkin Yayıncılık, 2019. 
Dilberoğlu, A. Vedat: "Cezalar ve Güvenlik Tedbirlerinin Amacı ve Niteliği”, Ankara Üniversitesi Hukuk Fakültesi Dergisi, Cilt: 65, Sayı: 4, 2016, 1517-1544.

Dönmezer, Sulhi/Erman, Sahir: Nazari ve Tatbiki Ceza Hukuku, Genel Kısım, Cilt: II, Sekizinci Bası, İstanbul, Filiz Kitabevi, 1983.

Dönmezer, Sulhi: "Suç Siyaseti”, İstanbul Üniversitesi Hukuk Fakültesi Mecmuas1, Cilt: 52, Say1: 1-4, 1987, 1-33, s. 7.

Dumlu, Hediye: “Thomas More'un Ütopya'sında Adalet Kavrayışı”, Ege Üniversitesi Sosyal Bilimler Enstitüsü, Yayımlanmamış Yüksek Lisans Tezi, 2014.

Erem, Faruk: Ümanist Doktrin Açısından Türk Ceza Hukuku, Cilt: II, 12. Baskı, Seçkin Kitabevi, 1985.

Fletcher, George P.: "Basic Concepts of Criminal Law”, New York, Oxford University Press, 1998.

Foucault, Michel: Hapishanenin Doğuşu, (Çev.: Mehmet Ali Kılıçbay), İmge Kitabevi, 2006.

Gözler, Kemal: Devletin Genel Teorisi, Bursa, Ekin Kitabevi, 2018.

Hofer, Paul J./Loeffler, Charles/Blackwell, Kevin/Valentino, Patricia: Fifteen Years of Guidelines Sentencing: An Assessment of How Well the Federal Criminal Justice System is Acheiving the Goals of Sentencing Reform, Kasim 2004.

Honig, Richard: “Ceza Gayeleri Nazariyesinin Tarihine Dair”, (Çev.: M. Yavuz Abadan), İstanbul Üniversitesi Hukuk Fakültesi Mecmuası, Cilt: 2, Say1: 0, 1936, 413-426.

Hudson, Barbara A.: Understanding Justice, 2. Bask1, Open University Press, 2003.

Işıktaç, Yasemin: “Ceza Adaleti Açısından Hapis Cezası ve Rehabilitasyon İlişkisi”, İstanbul Üniversitesi Hukuk Fakültesi Mecmuası, Cilt: 71, Say1: 1, 2013, 625-638.

İçel, Kayıhan/Sokullu, Füsun/Özgenç, İzzet/Sözüer, Adem/Mahmutoğlu, Fatih Selami/Ünver, Yener: Yaptırım Teorisi, İstanbul, 2000.

Karakaş Doğan, Fatma: Cezanın Amacı ve Hapis Cezası, İstanbul, Legal Yayınc1lik, 2010.

Kıdıl, Fahrettin: "Cezalandırmanın Amacı ve "Umut Hakkı" Bağlamında Koşullu Salıverilme Yasakları”, Türkiye Barolar Birliği Dergisi, Sayı: 138, 2018, 39-78. 
Koca, Mahmut/Üzülmez, İlhan: Türk Ceza Hukuku Genel Hükümler, Gözden Geçirilmiş ve Güncellenmiş 12. Bası, Ankara, Seçkin Yayınc1lik, 2019.

Kumar, Krishan: Ütopyacılık, (Çev.: Ali Somel), İmge Kitabevi, 2005.

Maden, Mehmet: Hapis Cezasına Seçenek Yaptırımlar, Ankara, Adalet Yayınevi, 2012.

More, Thomas: Utopia, Broadview Press, Peterborough, 2010.

More, Thomas: Ütopya (Çev.: Necmiye Uçansoy), İstanbul, Bordo Siyah Yayınları, 2007.

Nozick, Robert: Anarşi, Devlet ve Ütopya, 3. Baskı, İstanbul, İstanbul Bilgi Üniversitesi Yayınları, Nisan 2015.

Orwell, George: Bin Dokuz Yüz Seksen Dört, Can Yayınları, Mart 2008.

Önder, Ayhan: Ceza Hukuku Genel Hükümler, Cilt: III, İstanbul, Beta, Eylül 1989.

Özbek, Veli Özer/Doğan, Koray/Bacaksız, Pınar/Tepe, İlker: Türk Ceza Hukuku Genel Hükümler, 9. Baskı, Ankara, Seçkin Yayıncılık, 2018.

Özbek, Veli Özer: İnfaz Hukuku, 11. Baskı, Ankara, Seçkin Yayıncılık, 2019.

Öztürk, Bahri/Erdem, Mustafa Ruhan: Uygulamalı Ceza Hukuku ve Güvenlik Tedbirleri Hukuku, 18. Baskı, Ankara, Seçkin Yayıncılık, Eylül 2018.

Sokullu-Akıncı, R. Füsun: Kriminoloji, 13. Bası, Beta Yayıncılık, İstanbul, Eylül 2018.

Stillman, Peter Gordon: "Justice, Crime, and Punishment in More's Utopia" Pablo Guerra (Ed.) Utopía: 500 años, Ediciones Universidad Cooperativa de Colombia, 2016.

Şan, Zuhal: "Ütopyalarda Devlet Tasarımı: Platon, More, Campanella", Çukurova Üniversitesi Sosyal Bilimler Enstitüsü, Yayımlanmamış Yüksek Lisans Tezi, Adana, 2010.

Taner, Tahir: Ceza Hukuku Umumî Kısım, Üçüncü Basım, İstanbul, İsmail Akgün Matbaas1, 1953.

Tümerkan, Somay: "Klasik, Pozitivist Okullarda ve Toplumsal Savunma Hareketinde Ceza Sorumluluğunun Esası", İstanbul Üniversitesi Hukuk Fakültesi Mecmuas1, Cilt 48, Say1: 1-4, 1983, 51-71.

Ünver, Yener: Ceza Hukukuyla Korunması Amaçlanan Hukuksal Değer, İstanbul, Seçkin Yayıncılık, 2003. 
Üzülmez, İlhan: "Ceza Sorumluluğunun Esası ve Cezalandırmanın Amacına Dair Düşünce Hareketleri”, Atatürk Üniversitesi Erzincan Hukuk Fakültesi Dergisi, Cilt: V, Sayı: 1-4, 2001, 259-294.

Yarsuvat, Duygun: "Ceza ve Yeni İçtimai Müdafaa Doktrini”, İstanbul Üniversitesi Hukuk Fakültesi Mecmuas1, Cilt: 32, Say1: 1, 1966, 79100.

Young, Peter: "The Importance of Utopias in Criminological Thinking”, The British Journal of Criminology, Cilt: 32, Say1: 4, 1992, 423-437.

Yüce, Turhan Tûfan: Ceza Hukuku Dersleri, Cilt: I, Manisa, Şafak Basım ve Yayınevi, 1982. 